\title{
Pogrebni obredi i ukopi na istarskim gradinama u brončano doba
}

\author{
Pregledni rad \\ Review article \\ UDK 930.2:393>(497.5-3 Istra)"637"
}

\begin{abstract}
Istra je u brončano doba naseljena indoeuropskim stanovništvom koje je svoje tajne života i smrti ostavilo budućim generacijama u svojim posljednjim počivalištima. Grobovi na ravnom i tumuli, kamene građevine kružnog oblika, jedni su od glavnih karakteristika brončanog doba. Upravo su nekropole, gradovi mrtvih smješteni u blizini gradova živih, dali istraživačima tog davnog razdoblja uvid u način života, običaje i vjerovanja stanovništva koje je kročilo tim istim prostorom više tisuća godina prije nas. Tema ovog članka predstavlja pokušaj da se na jednom mjestu analiziraju svi dostupni podaci o obredima i ukopima u Istri u brončano doba.
\end{abstract}

Ključne riječi: Istra, brončano doba, gradine, tumuli, obredi, Maklavun, Žamnjak, Monkodonja, grobni prilozi

P

osmrtni ostaci, grobovi i grobni prilozi vrlo su važni materijalni izvori za proučavanje prošlosti. Upravo iz posmrtnih ostataka, načina pokopa te grobnih priloga današnje će znanosti (arheologija, antropologija...) istražiti mnoge aspekte života tadašnjih ljudi, od načina života, prehrane do religije.

Proučavajući brončano doba u Istri, moderna će se znanost uvelike koristiti materijalnim povijesnim izvorima pronađenim na posljednjim prebivalištima brončanodobnih stanovnika Istre. Taj će naš daleki predak, brončanodobni Istranin s karakterističnim ukopom pod gomilom kamenja - tumulom ili, kako bi u Istri rekli, gromačom, ucrtati u naš krajolik svoj karakterističan potpis, koji je već stoljećima predmetom istraživanja. Mjesta njegovog stanovanja i pokopa često se nalaze u lokalnim legendama i pričama o starim narodima koji su zakopali "tu negdje" svoje blago. Upravo iz tumula, nakupine kamenja koja skriva pokojnika s kakvim prilogom keramike i jantara, započinje priča o brončanodobnom stanovniku, njegovom životu, smrti i vjerovanju na koju se nadovezuje naša civilizacija.

\section{Brončano doba}

Metal će uvelike promijeniti način života ljudi: od razvitka trgovine, obrta do utjecaja na migracije koje će mnogostruko utjecati na smjenu neolitskog stanovništva Indoeuropljanima. Upotreba metala dovela je do raslojavanja i diferenciranja zajednice, budući da metalni predmeti kao simboli moći već u bakreno doba pomažu vođama "da učvrste svoj položaj". 
U brončano doba snaga je metalnog oružja neupitna, a zlato i srebro postat će simboli bogatstva i moći vladajućeg sloja. Metal kao izraz vrijednosti zamijenit će stoku, žito ili neke druge proizvode. Lakše se prenosi, poklanja i gomila te nasljeđuje s koljena na koljeno. Na taj način povezuje i konsolidira prve dinastije, čija će nit vodilja biti vlast na određenom prostoru nad određenom zajednicom. Takav oblik vlasti ući će u povijest pod nazivom poglavništvo (Heršak 2005: 113).

Od početka istraživanja života na gradinama u Istri više je teorija o datiranju brončanog doba. Čović je, prateći srednjoeuropsku kronologiju brončanog doba, utemeljio dataciju tog doba u Istri. On dijeli rano i srednje brončano doba u tri faze: Istra 1 - brončano doba A-1 (početna faza koja pripada početku brončanog doba), Istra 2 - brončano doba A2 - B1 (rana brončana kultura koja prelazi u srednje brončano doba), Istra 3 - brončano doba B2 - C (srednje brončano doba) (Čović 1983: 133).

Istra 1 odnosi se na nalaze priobalnih naselja Javorike - Gromače na Velikom Brijunu te pećinama Trogla, Srbani i Cingarela. Čović tu smješta i područje hramova u Poreču te tumule Valmarin i Bombišta u okolici Pule. Razdobljem Istra 2 Čović naziva razdoblje gradina te ističe istražene gradine Vrčin, Mordele, Magornjak, Vintijan i Glavica kraj Pule, tumule Žamnjak i Maklavun, i sloj između 0,90 m i 1, 80 m u Trogrloj pećini. Posebno je važan Mali sveti Anđeo kao kultna građevina s vjerojatnošću datiranja gradine Veliki sveti Anđeo u isto razdoblje. U razdoblje Istra 3 po Čoviću spadaju gradine Veliki Brijun i Monkodonja, tumul Novi grad kraj Krmeda, s mogućnošću da su nalazi iz grobova s Šandalje, Peroja i Vintijana također iz ove faze (Čović 1983: 134).

Cardarelli je analizom keramičkog materijala s gradina Trsta i okolice te s gradina Istre odredio podjelu brončanog doba od srednjeg brončanog doba do prvog stupnja željeznog doba. Treba istaknuti da je u Istri 11. i 10. st. pr. Kr. zbog prodora kulture polja sa žarama, smješteno u kasno brončano doba srednjoeuropske kronologije (Cardarelli 1983: 87-104).

Osim Čovića i Cardarellija, dataciju brončanog doba predložila je i Biba Teržan, koja je, uspoređujući materijal istraživanja s Monkodonje s materijalima cetinske kulture, Tršćanskog krasa, s nalazima sjevernotalijanskih, srednjoeuropskih, jugoistočnih brončanodobnih nalazišta, odredila karakteristične tipove kraja ranog i početka srednjeg brončanog doba u Istri. Njezina se datacija djelomično podudara s Čovićevom, a djelomično s Cardarellijevom. Po njoj se rano brončano doba dijeli na početnu i razvijenu fazu, koje karakterizira nastanak većine gradina. Srednje brončano doba dijeli također na stariju i mlađu fazu, a u kasno brončano doba ističe pojavu kulture polja sa žarama (Teržan u: Hänsel et al. 1999: 83-95).

\section{Obredi i ukopi u brončano doba}

Grobovi su oduvijek imali posebno mjesto u kulturama kao mjesto gdje se susreće svijet mrtvih i svijet živih. Grob se poima kao pokojnikova kuća, a sama su groblja naselja mrtvih, kao što i sam grčki naziv nekropolis govori. Smatra se da je grob kao i kuća - dom, jedna od odrednica identiteta kulture pojedinog naroda. Groblja su dio smišljenog rituala, čija je svrha ostavljanja znaka budućim generacijama. Ceremonijalna briga za mrtve jedna je od prvih karakteristika koja je odvojila čovjeka od životinja. Groblja su mjesta vraćanja, odavanja počasti i nastojanja stupanja u kontakt s duhovima svojih predaka. Gradovi mrtvih bili su preteča gradova živih i pružaju odraz života ljudi čije su posljednje prebivalište (Mumford 1988: 8-9).

Grobovi su neiscrpan izvor podataka koji se mogu podijeliti na materijalne izvore prilozi poklonjeni pokojniku, nošnje (odjeća, obuća, nakit); antropološki podatci (spol, dob preminulih, uzrocima smrti), dok DNA analize otvaraju nove poglede na porijeklo i kretanja 
pojedinih narodnosnih skupina, od pojave ljudi do danas (Težak-Gregl 2011: 153). Još od neolitika možemo pratiti različite priloge koji su smješteni uz pokojnika za zagrobni život. U brončanom dobu prilozi se mijenjaju te nam ukazuju na znakovite promjene u društvu. Osim predmeta u grobovima, veliki broj ulomaka keramike ukazuje na rituale koji su se obavljali prilikom pokopa. Takvi ostatci mogu upućivati na libacijske obrede i ritualno razbijanje keramičkih posuda nad pokojnikovim grobom. Egzotični predmeti poput jantara mogu nam dati saznanja o ulozi pojedinca u društvu zajednice te religijsku praksu koja nam omogućuje i uvid u segmente duhovnog života društva kojem je pokojnik pripadao. Po mnogim pronađenim artefaktima možemo pretpostaviti da je ljudski rod od pamtivijeka vjerovao u nekakav oblik besmrtnosti duše i njezin prelazak u drugi, vječni zagrobni život.

Osim dvije najučestalije vrste ukopa, kosturni ukop ili inhumacija i paljevinski ukop ili incineracija, tijekom prapovijesti prakticirali su se i sekundarni ukopi. Kod kosturnog ili skeletnog ukopa razlikujemo ukop po položaju tijela koji može biti zgrčen, ispružen ili sjedeći. Kod ukopa koji razlikujemo po položaju ruku, ruke mogu biti ispružene, prekrižene na prsima ili prekrižene ispod tijela. Ukop se razlikuje i po položaju glave ili lica prema određenom smjeru te prema opremi gdje se ljesovi izrađuju od različitih materijala kao što su deblo, glina, kamena, ili velike keramičke posude. Grobovi pokojnika mogu biti pojedinačni ili skupni. Skupni grobovi mogu biti i mjesta pokapanja jedne zajednice na duže vrijeme u kojoj se odlažu posmrtni ostaci. Ponekad se prijašnje posmrtne ostatke samo uklanjalo na stranu, a često se ukopi prijašnjih osoba ne oštećuju. Osim skeletnog ukopa u brončano doba, ukop pokojnika vrši se i incineracijom, odnosno spaljivanjem. Incineracija je zabilježena već u neolitiku, ali je karakteristična za kulturu polja sa žarama i željezno doba. Oblici ukopa spaljenih ostataka pokojnika mogu se položiti u običnu jamu ili rastresiti grob te u žaru (Težak-Gregl 2011: 156-158). U nekim slučajevima prilozi se spaljuju zajedno s pokojnikom, a ponekad se prilažu naknadno u žaru ili se ostavljaju pored nje.

Grobovi ili grobnice dijele se na više vrsta: grobovi na ravnom, ukop pod humkom, zidani grob te jamni ukop. Kod ukopa u jami ne možemo sa sigurnošću tvrditi kako je izgledala površina groba. Pojedini nalazi ukazuju na obilježavanje površine kamenim popločenjem, kamenim vijencem ili pokrovnom pločom (Težak-Gregl 2011: 158).

Ukop pod humkom ili tumulom karakterizira grob u jami koji je pokriven kamenjem ili zemljom. Često se sreće, a može se reći da je čak i karakterističan za Istru brončanog doba. U narodu je poznat pod nazivom gromača ili gomila. Javlja se u brončano doba u kojem dolazi do diferencijacije društva u kojem se pojedinac ili društveni sloj odvaja od ostalih te se nastoji istaknuti važnost pokojnika u toj zajednici.

Treća su vrsta grobova zidane grobnice koje se mogu zidati od mnogih materijala, najčešće od kamena zbog čvrstoće, zatim opeke te drva (Težak-Gregl 2011: 158). U ovakve grobnice spadaju tholosi - kružne kamene grobnice s kupolom. Zidane grobnice megalitskog tipa sagrađene od velikih kamenih blokova javljaju se diljem Europe.

Posebnu kategoriju predstavljaju prazni grobovi ili kenotafi kada je tijelo pokojnika nedostupno.

\section{Život na istarskim gradinama}

Jedno od glavnih pitanja vezano uz gradine jest pitanje njihove datacije, odnosno, vrijeme njihova nastanka. Je li zauzimanje uzvisina nastupilo odmah pri dolasku novog stanovništva ili nešto kasnije? Da li su skupine ljudi najprije naselile pećine? Da li su, ako su i zauzeli strateške vrhove, odmah započeli s gradnjom obrambenih sistema? Postoje mišljenja da je većina gradina nastala krajem ranog i početkom srednjeg brončanog doba (Čović 1983: 122, 
Cardarelli, 1983: 87). Zbog karaktera nalaza (slabe istraženosti i uniformiranosti, odnosno teško definirane stratigrafije), pitanje i dalje ostaje otvoreno i u Istri i na drugim prostorima (Slovensko primorje) (Sakara Sučević 2011: 8-9)

Gradine kao dio antropičnog krajolika predstavljaju zanimljivost po svom položaju, obliku i brojnosti. ${ }^{1}$ One su uvijek nastajale na strateškim položajima koje je bilo jednostavno zaštiti kamenim bedemima (Mihovilić 1987: 17) ili su već imale prirodnu zaštitu (Buršić-Matijašić 2007: 168). Oblik gradine, kao i veličinu i oblik bedema uvjetovalo je mjesto na kojem je bilo izgrađeno naselje. Gradine mogu biti raznih oblika, pravilnih i nepravilnih, a najčešće su kružnog, ovalnog, potkovičastog i četvrtastog oblika. Bedemi jednostruki, dvostruki ili čak trostruki, koji su štitili takvo naselje, bili su građeni od grubo obrađenih kamenih blokova. Osim bedemima, gradina je često bila zaštićena labirintskim sustavom ulaza i prolaza (Baćić 1970: 215-227). S obzirom na namjenu, gradinska naselja najčešće imaju karakter stalnog boravka, međutim, neke gradine mogle su služiti za povremeno korištenje u slučaju opasnosti. U takva naselja privremenog karaktera spadaju i ona koja su služila za kultne potrebe ili za povremeno sklanjanje stoke. Ponekad su takva naselja prerasla u naselja stalnog karaktera (Buršić-Matijašić 2007: 85). Najbolji primjer naselja namijenjenog stalnom boravku ljudi jest Monkodonja kraj Rovinja. Zahvaljujući višegodišnjim istraživanjima dobiveni su mnogi vrijedni podatci o veličini, izgledu, ustroju, građevinskim elementima, materijalnoj kulturi, gospodarstvu, socijalnoj strukturi i broju stanovnika. Osim gradinskih naselja na uzvisinama, $\mathrm{u}$ isto su vrijeme postojala i izvangradinska naselja smještena na blagim zaravnima i na rubovima polja. Imali su karakteristike neolitskih naselja, a zabilježene su i u brončano doba u Istri. U posljednjih nekoliko godina zabilježena su pojedina naselja na lokalitetima Boškina kraj Krvavići, Kornede s kraj Gurana, Vinjan s kraj Loborike te Stari Guran, koji je ujedno i najistraženiji (Mihovilić, 2009: 48).

\section{Brončanodobni ukopi u Istri}

S obzirom na slabu istraženost prapovijesnog naselja u određivanju datacije brončanog doba, veliki naglasak dan je ukopima. U narednim redcima bit će prikazani brončanodobni grobovi u kronološkom slijedu objavljeni u "Praistoriji jugoslavenskih zemalja" (Čović 1983: 114-137, Batović 1983: 236-298).

Na samom početku ranog brončanog doba (Istra I - brončano doba A 1) ne postoje pouzdani podaci o ukopima tadašnjih stanovnika. Vjerojatno se već onda pojavljuju prvi ukopi u tumulima, gdje se pokojnik polagao u zgrčenom položaju u grobne škrinje. Ovom razdoblju najvjerojatnije pripadaju tumuli Marin dol kod Pule i Bombišta kraj Banjola. Oni su istraživani početkom 20. st., no danas su nažalost oba devastirana. Ustanovljen je običaj da se dno grobne škrinje prekrije kamenim oblucima donesenim s morske obale. Taj običaj pojavljuje se i kod nešto mlađih grobnica u Istri. Pretpostavlja se da ukop u tumulu obilježava i drugu fazu ranog brončanog doba. Nalazimo ih na Žamnjaku i Makalavunu. Takvi kružni grobni spomenici zidani su od kamenih ploča i krupnijeg kamena. U unutrašnjosti tumula, koja je bila ispunjena kamenim nasipom, nalazio se grobni sanduk građen od kamenih ploča. Položaj pokojnika u grobu je zgrčen, na boku, a pojavljuju se i ukopi u sjedećem položaju. Posebno su zanimljivi tumuli na Maklavunu i Žamnjaku, budući da su prilikom istraživanja kod njih pronađene posebnosti koje nisu zamijećene na drugim istarskim tumulima, no o tome će biti riječ nešto kasnije. Tumuli se pojavljuju pojedinačno, najčešće su smješteni na dobro vidljivom mjestu, ali i u većim ili manjim skupinama. Najčešće u grobnicama nema priloga,

Istraživači u Istri bilježe više stotina gradina: Marchesetti - 350, Buršić-Matijašić - 436 (Marchesetti 1903: 18, Buršić-Matijašić 2007: 582). 
osim dijelova razasute keramike u tumulu i oko njega (Čović 1983: 120-125). Zanimljiva je pojava kružnog zida kod nekih tumula, koji je zasigurno bio jedan od važnih elemenata u kultu mrtvih zajednica (Benac 1984: 141). Pretpostavlja se da se takav zid podizao kako bi štitio od negativnih utjecaja zagrobnog života ili je pak predstavljao zaštitu posvećenog mjesta od vanjskih utjecaja (Buršić-Matijašić 2003: 181).

Za srednje brončano doba u Istri i dalje je karakterističan ukop u tumulu. U ovom razdoblju, međutim, pojavljuje se i jedan novi oblik ukopa - ukopi u ozidanim i ukopanim ravnim grobovima unutar ili izvan naselja. Jedna takva manja nekropola bila je nađena, ali je nažalost potpuno uništena na Brijunima u 19. st. Ti grobovi imali su potkovičasti oblik, a njihova veličina ukazuje na ukop u zgrčenom položaju. Smatra se da bi ovom razdoblju mogli pripadati i grobovi od kamenih ploča, ukopani u zemlju, ali bez grobnog humka. U grobovima je bilo ukopano više osoba, bez grobnih priloga. Takvi grobovi zabilježeni su na Vintijanu, Peroju i Šandalji. Takva vrsta grobova, zajedno s nekropolom na Velikom Brijunu, možda ukazuje na postepeno napuštanje ukopa pod tumulom, ali uz zadržavanje oblika grobnice, kao i položaja pokojnika u njima. To bi mogli potvrditi i grobovi s gradine Vrčin, koje Batović datira u kasno brončano doba (Batović 1983: 236).

Za početak kasnog brončanog doba Batović navodi dva moguća načina ukopa, nastavlja se tradicija ukopa pod kamenim gomilama, a pojavljuju se zajednička groblja na ravnom zemljištu koja se nalaze unutar naselja ili izvan njega. Pokojnici bi bili polagani u zgrčenom položaju na bok u grobne škrinje načinjene od četiri okomito položene kamene ploče. Najčešće su bili prekriveni pločom preklopnicom, a dno je bilo obloženo pločom, popločano ili posuto $s$ kamenim šljunkom. Neki grobovi su izvana poduprti kamenjem ili suhozidom. Kako bi se grobna škrinja što bolje spojila i bila čvršća, grobne ploče mogle su imati i žljebove. Pretpostavlja se da gradnja groba u obliku škrinje oponaša kuću živih. Uz ukop u zgrčenom položaju, pojavljuje se i nov način ukopa u sjedećem položaju (na Vrčinu i Novom gradu kraj Krmeda). U Istri su pronađeni grobovi s jednom, ali i s većim brojem pokopanih osoba (Batović 1983: 288). Duh pokojnika poštivali su i stanovnici kasnog brončanog doba koji su kosti prijašnjih ukopa pomicali i spremali u jedan dio groba prije novog ukopa (Buršić-Matijašić 2007: 536).

Zajednička groblja na ravnom zemljištu mogu se nalaziti izvan bedema, kao što je to slučaj s grobovima u Vrčinu ili unutar bedema, kao što su grobovi na Brijunima i u Peroju. Takvi zajednički grobovi ili skupine grobova često su bili ograđeni suhozidom te su na taj način najvjerojatnije označavali grobne prostore pojedinih rodova ili obitelji (Batović 1983: 288). Nekropole koje su se nalazile uz bedeme imale su funkciju duhovne i fizičke prepreke u naselje. To je zasigurno bio jedan vid obrane naselja, budući da su i tadašnji stanovnici vjerojatno vjerovali u prokletstvo onoga koji uništi grob (Buršić-Matijašić 2008: 255).

Tragovi duhovnog života istarskih brončanodobnih stanovnika mogu se naslutiti u raznim oblicima: kultu mrtvih, grobnim prilozima, tragovima obreda i dr. Dva prisutna načina ukopa kroz brončano doba označavaju i dva različita obreda sahranjivanja, međutim potpuni sadržaji tih obreda nisu u potpunosti poznati. Svaki od ta dva ukopa ima karakteristične vrste priloga i ostatke obreda. U grobovima na ravnom zemljištu pronađen je nakit, dok su u tumulima uz nakit pronađeni i prilozi, poput dijelova zemljanih posuda. Česti su nalazi kosti životinja koji vjerojatno svjedoče o obredu vezanom uz prilaganje posude s hranom u ili uz grob. Takvi obredi izvodili su se prilikom podizanja tumula ili nakon stavljanja pokojnika u grob (Batović 1983: 298). Neki znanstvenici smatraju da se kod razbijanja posuđa radi zapravo o jednom vidu daće, u kojoj je libacija, odnosno ostavljanje hrane praćeno razbijanjem posude u kojoj se ona nalazila (Benac 1984: 144).

Arhitektura istarskih tumula i grobnica brončanog doba dokaz nam je o povezanosti istarskog poluotoka s istočno sredozemnim kulturama brončanog doba. To nam potvrđuju i brončani bodeži nađeni u nekolicini grobova (Mihovilić 2009: 54). 


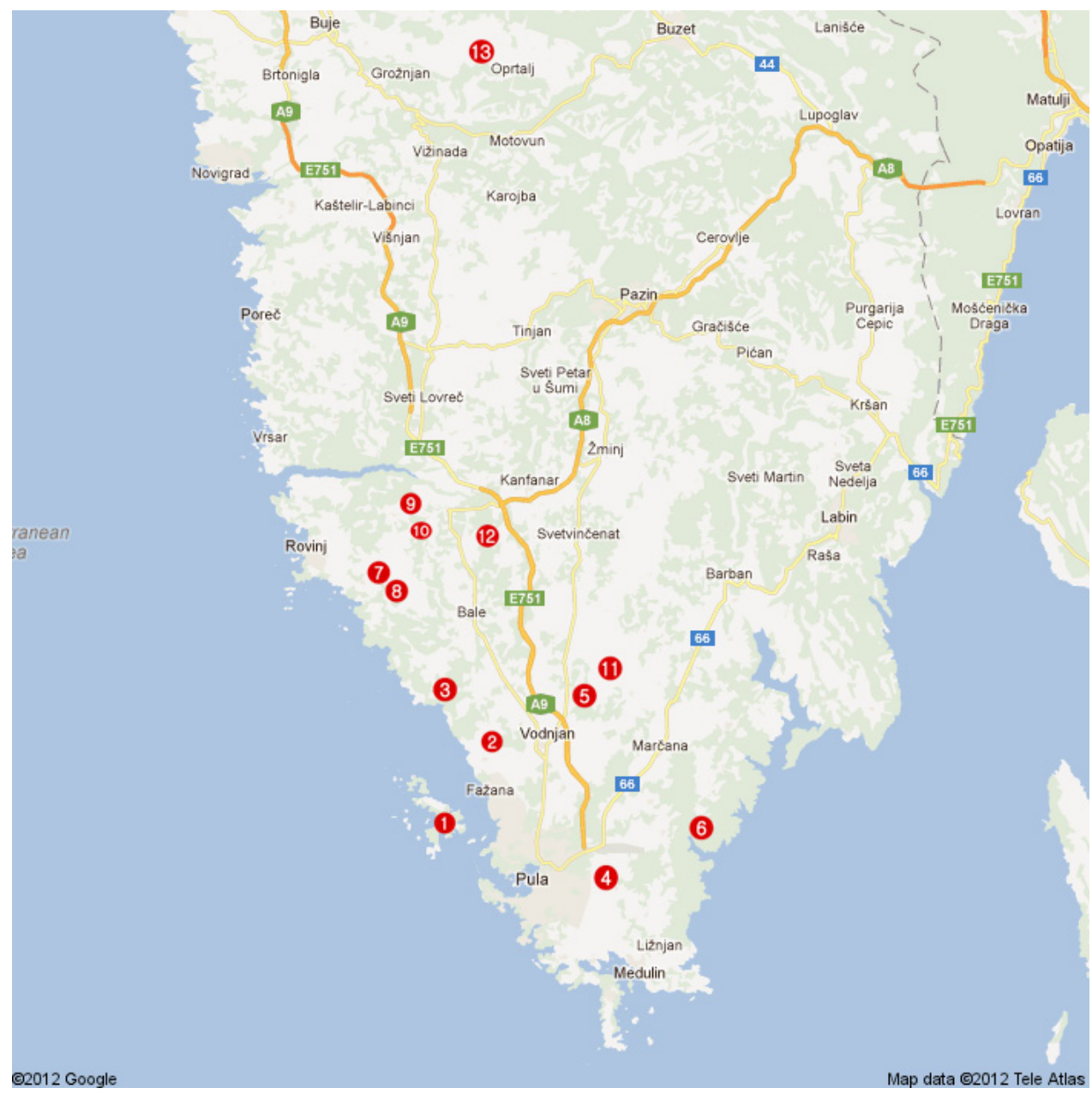

SI. 1: Karta s istraženim brončanodobnim ukopima: 1. Gradina na Velikom Brijunu; 2. Magornjak; 3. Uvala Marić; 4. Šandalja; 5. Škicini; 6. Vela gromača; 7. Monkodonja; 8. Mušego; 9. Maklavun; 10. Žamnjak; 11. Vrčin; 12. Novi Grad; 13. Pećina Laganiši

\section{Gradina na Velikom Brijunu}

Sjeverozapadno od Pule, paralelno s istarskim kopnom proteže se arhipelag Brijuni. Od četrnaest otoka i otočića najveći je otok Veliki Brijun (Fabjanović et al. 2005: 101). Iznad zaljeva Verige na $42 \mathrm{~m}$ nadmorske visine nalazi se Gradina na kojoj je istražena nekropola s nekoliko ravnih grobova. Današnji vrh Gradine predstavlja prostor omeđen trima obrambenim zidinama. Najbolje je sačuvan najviši, tj. prvi obrambeni pojas s naknadno dograđenim ulaznim predprostorom (Vitasović 2002: 10). Gradinu prvi spominje A. Puschi, a 1900. istražuje je i Anton Gnirs, koji dopunjuje Puschijeve teze o zagrobnom životu, obrazlažući ih grobnom arhitekturom potkovastog oblika. Godine 1974. istraživanja započinje Anton Vitasović, koji otkriva veću količinu keramike u procjepima između većih stijena, jednu kamenu sjekiru i nekoliko kamenih nožića. Na južnoj strani gradine otkriva i obiteljski grob smješten između drugog i trećeg obrambenog pojasa, a na zapadnoj strani još jedan samostalan grob (Vitasović 2002: 6). 
Obiteljski grob (sl. 2) sastoji se od groba djeteta te dvije grobne cjeline. U njegovoj se arhitekturi može primijetiti da su se grobovi omeđivali s velikim vertikalnim kamenim pločama. Dno groba bilo je posuto malim morskim valucima na koje bi se polagao pokojnik. Potpuno je ostao sačuvan jedino grob djeteta koji su činile dvije vertikalno usađene paralelne kamene ploče. Između njih su u suhozidu dozidane čeone stranice. Dubina groba je $44 \mathrm{~cm}$, a dimenzije grobne cjeline jesu $66 \times 22 \mathrm{~cm}$. Istraživači su zamijetili da je kamenje koje je korišteno za izgradnju grobne arhitekture pripadalo nekoj starijoj grobnici, budući da su vidljivi tragovi nalijeganja. Grob koji je bio udaljen desetak metara od obiteljskog groba omeđen je dvjema uzdužnim pločama, a vidljivi su i tragovi nalijeganja čeonih ploča. Van groba nađeni su dijelovi keramike i ljudskih kostiju, što potvrđuje da je grob bio otvaran prije istraživanja. Od samostalnog groba prema obiteljskom grobu nalazi se "potkovasta konstrukcija", na čijoj je površini nađen veliki broj morskih valutaka s vidljivim tragovima obrade. Kasnija istraživanja otkrivaju još nekoliko manjih potkovastih konstrukcija za koje Vitasović pretpostavlja da su bile grobne cjeline (Vitasović 2002: 17). U prostoru izvan grobnih arhitektura nalaze se nepravilno usađene ploče. Osim nalaza ljudskih kostiju na površini pronađena keramika je nekarakteristična, izuzev poluloptaste posude s ravnim dnom, loptaste posude s ravnim dnom te široke plitke zdjele. Kao grobni prilog, uz keramiku je nađen i mali koštani privjesak (Vitasović 2002: 14).

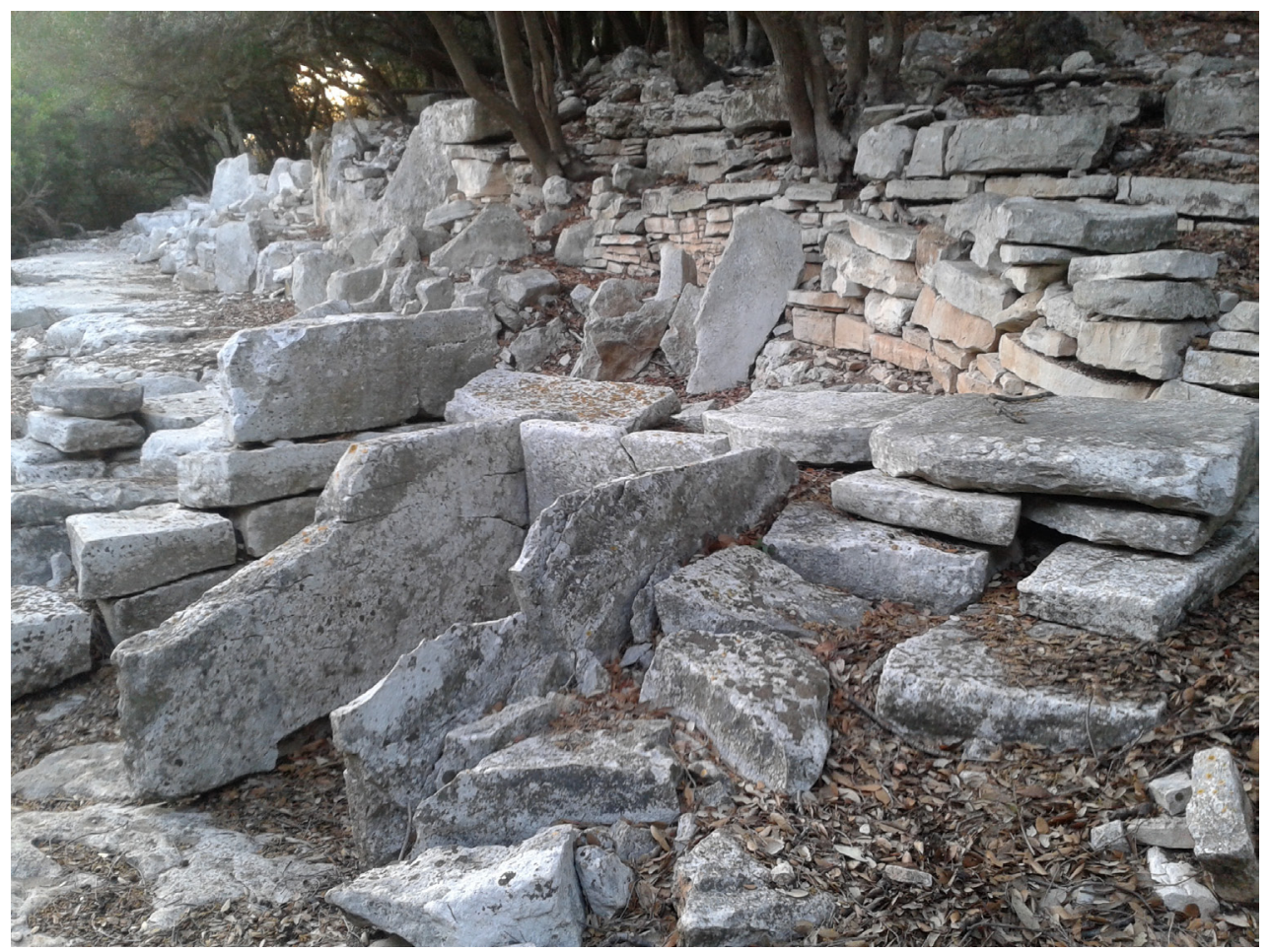

SI. 2: Grob na Gradini na Velikom Brijunu (snimila Hana Žerić Šaponja, srpanj 2012.)

\section{Magornjak}

Gradina Magornjak nalazi se istočno od mjesta Peroj. Godine 1954. tijekom građevinskih radova radnici su naišli na grobne kamene ploče. Dolaskom arheologa utvrđeno je da 
grob, koji je djelomično bio uništen, datira iz brončanog doba. Grobnica, čije su unutarnje dimenzije bile: širina $60 \mathrm{~cm}$, dužina $116 \mathrm{~cm}$ i visina $68 \mathrm{~cm}$, bila je orijentirana u smjeru sjever - jug i činilo ju je šest kamenih ploča. Gornja ploča bila je polegnuta na donje, vertikalno položene ploče i prelazila je preko njihova ruba. Duže pobočne ploče imale su uklesane žljebove (1-2 cm dubina, $8-10 \mathrm{~cm}$ širina) kako bi se pobočne manje ploče što bolje učvrstile (Baćić 1954: 15).
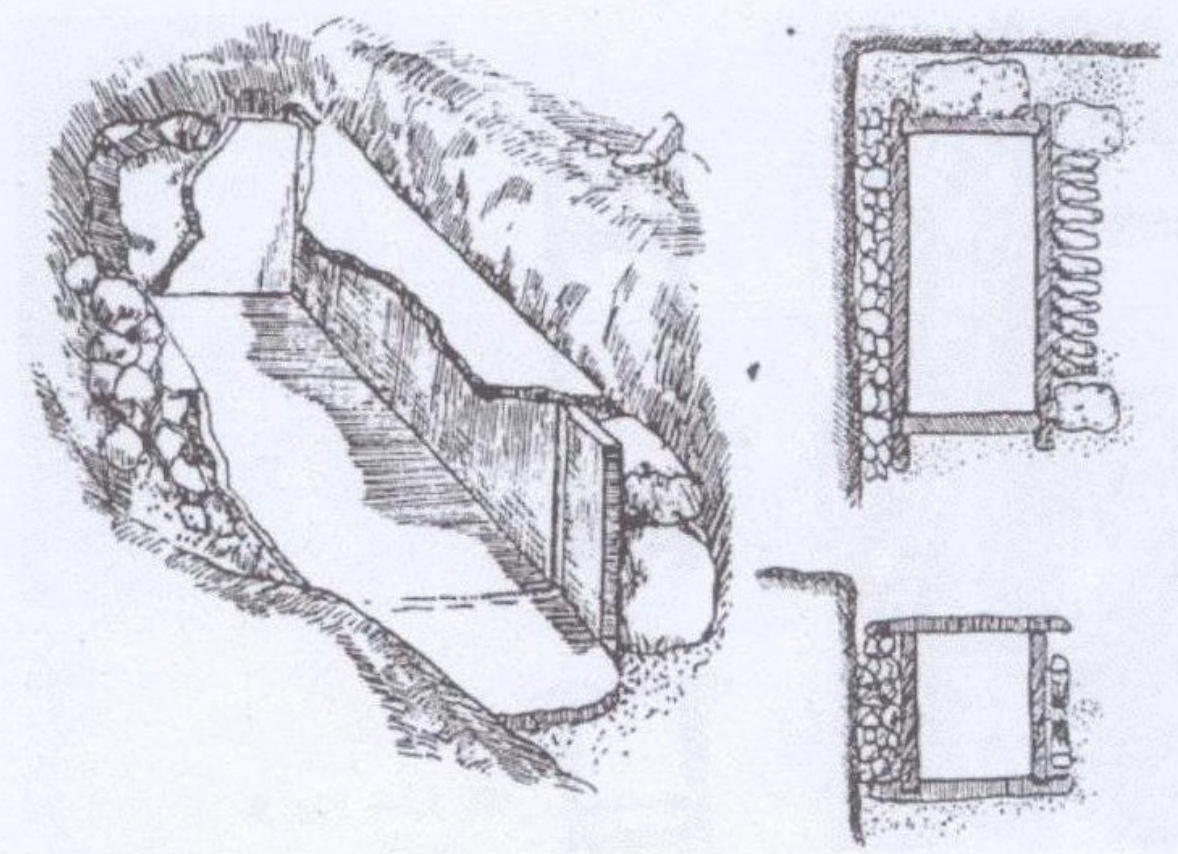

\section{Sl. 3: Magornjak (Baćić 1954-1957)}

Kod groba pronađenog na Magornjaku zabilježena je prvi put i jedna posebnost u gradnji. Kamene ploče grobnog sanduka, koje su u drugim slučajevima ukopane u zemlju, ovog puta bile su dozidane izvana još jednom dodatnom gradnjom. Tako se na zapadnoj strani duža pobočna ploča naslanjala na suhozid. Zid je građen tako da je na oba kraja poluobrađeno kamenje bilo horizontalno polegnuto jedno na drugome, dok su se između njih nalazila dva reda ukoso posloženih kamenih ploča. Uža južna kamena ploča naslanjala se na ploču koja je bila mnogo deblja i masivnija od nje. Nažalost, ne zna se kakvo je bilo stanje na sjevernoj strani jer je do dolaska arheologa ta strana već bila uništena (Baćić 1954: 16).

Grob je bio poprilično duboko ukopan i ne postoji nikakav trag je li bio obilježen grobnim humkom, odnosnom gromačom. Možda je gromača i postajala, ali je kroz povijest uništena i sravnjena sa zemljom. Ukop je svakako morao biti nekako označen, ako to nije bila gromača onda se iznad groba nalazio neki veći kamen koji je služio kao pogrebna stela. Budući da se blizu ovog prapovijesnog lokaliteta u antici nalazio seoski gospodarski posjed. (Matijašić 2005: 286) možemo pretpostaviti da je i tijekom tog razdoblja dio groba devastiran. Na temelju sačuvanih ostataka utvrđeno je da su se u grobu nalazila tri kostura, dva pokojnika starije dobi, neutvrđenog spola, dok je treći pokojnik bio muškarac mlađe dobi. U grobu su 
pronađeni dijelovi keramičkog lončića s drškom karakterističnom za rano brončano doba (Baćić 1954: 15 - 16).

\section{Tumul iznad uvale Marić}

$\mathrm{Na}$ širem području Barbarige nazvanom Veliki komunal, prilikom zaštitnog istraživanja 2003., otkrivena je skupina tumula. Tumuli se rasprostiru između ceste koja vodi od turističkog naselja Barbariga prema staroj Stanciji Barbariga, međutim, zbog guste vegetacije nije utvrđena krajnja granica njihova rasprostiranja. Tumuli su pravilno raspoređeni u osam redova u smjeru sjeveroistok - jugozapad, a razmak između pojedinih tumula u svakom redu iznosio je između 32 i 38 m, a u većini slučajeva taj razmak iznosio je $35 \mathrm{~m}$. Uz tumule uočen je i devastirani suhozid, paralelan s redovima tumula. Buduća istraživanja dat će odgovore je li riječ o ostacima rimske centurijacije ili prapovijesnom groblju (Codacci-Terlević 2006: 54).

Između manjih tumula do izražaja je dolazio veći tumul koji se blago nazirao iznad razine terena i nalazio se na najvišoj koti brda Komunal. Tumul je bio izrazito slabo sačuvan. Na jednoj strani tumula sačuvan je samo jedan red kamenja, a na sjeveroistočnoj strani sačuvano je i do tri, četiri reda. Suhozid, čija je visina vjerojatno bila oko 0,5 metara, okruživao je grob koji se nalazio u sredini. Na nekim mjestima bio je vidljiv još jedan suhozid kružnog oblika, paralelan s vanjskim, međutim, mnogo je slabije sačuvan. Postoji mogućnost da je grobnica bila zaštićena s dva suhozida koji su imali oblik vijenca. Unutar kružne konstrukcije, između kamenja pronađena je keramika. lako je bila u izuzetno fragmentiranom stanju, analizom oblika i frakture uspjelo se datirati grob u drugu fazu rano brončanog doba. Uz keramiku pronađeno je i nekoliko ulomaka životinjskih kostiju i nekoliko morskih školjaka (CodacciTerlević 2006: 55-56).

U sredini tumula nalazio se grob koji je već bio devastiran, nedostajala je velika ploča poklopnica. Grob u uvali Marić, kao i onaj na Maklavunu, bio je sagrađen tehnikom suhozida. Nije bio postavljen na živu stijenu, već je bio sagrađen na povišenom sloju kamenja i zemlje u smjeru sjeverozapad - jugoistok. Veličina groba bila je $147 \times 75 \mathrm{~cm}$, a visina unutar grobnice je $50 \mathrm{~cm}$. Unutar groba nađena je i mala količina morskih oblutaka, morskih puževa i morskoga pijeska. Uz pronađenu keramiku, u tumulu je nađen i keramički ulomak tamnosmeđe boje i izglačane površine. Imao je uvučeno dno i u sredini rupu izvedenu prije pečenja posude. Kako je predmet nađen unutar tumula, pretpostavlja se da ima kultnu svrhu vezanu uz rituale prilikom pokapanja (Codacci-Terlević 2006: 56-61).

\section{Šandalja}

Gradina Šandalja u blizini Pule višeslojno je arheološko nalazište. Prapovijesna gradina devastirana je gradnjom vojne utvrde krajem 19. i početkom 20. st. (Buršić-Matijašić 2007: 138), a širenjem obližnjeg kamenoloma uništeno je i dvanaest brončanodobnih grobova. Grobovi su bili smješteni na istočnoj strani van gradinskog bedema, a od dvanaest uništenih grobova sačuvao se samo jedan. Grob je bio načinjen od pet kamenih ploča. Duže kamene ploče imale su usjeke u koje su ulazile kraće bočne ploče. Ploča preklopnica imala je usjeke na donjoj strani. Dno groba činio je debeli sloj sitnog šljunka i bio je ukopan između prirodnih stijena (Baćić 1954: 18).

Na temelju sačuvanih antropoloških ostataka utvrđeno je da je jedan pokojnik bio starije dobi dok je drugi imao ispod dvadeset godina. $U$ grobu su nađeni samo dijelovi grube i slabo pečene keramike (Baćić 1954: 17-18). 


\section{Škicini}

Mjesto Škicini nalazi se 5 km sjeverno od Vodnjana. Prilikom zemljanih radova 1989. godine razorena je jedna gromača te su izvršena zaštitna istraživanja. Ispod tumula promjera tri metra nalazio se grob s dva pokojnika (Buršić-Matijašić 2003: 171). Grob je bio sastavljen od dvije manje i dvije veće ploče te pločom poklopnicom koja je bila masivnija od ostalih ploča. Jedna kraća ploča koja se nalazila na bočnom položaju groba s vanjske strane bila je osigurana suhozidom. Dužina grobnog sanduka bila je $100 \mathrm{~cm}$, a širina $50 \mathrm{~cm}$. Orijentacija groba bila je istok - zapad. Dno groba činila je utabana zemlja. Uz ostatke dva pokojnika, kao grobni prilog nađen je nakit, brončana ogrlica i jantarne perle. Nađeni su i ulomci keramike koji su bili u izbačenom materijalu, no ne zna se je li to materijal iz groba ili materijal koji je bio razbacan po gomili. Pronađen je ulomak keramičke zdjele tankih stijenki, kakav se nalazi i na gradinama Monkodonja, Vrčin u Istri i na gradinama Caput Adriae i spada u razdoblje srednjeg brončanog doba, no s obzirom na to da ne predstavlja forme karakteristične za dataciju, autorica ga ne smatra relevantnim za dataciju ukopa (Buršić-Matijašić 2003: 175). Jantarne perle od kojih je jedna debljine $2,8 \mathrm{~cm}$ i promjera $2,8 \mathrm{~cm}$, a druga promjera $1,6 \mathrm{~cm}$ i promjera $0,5 \mathrm{~cm}$ vjerojatno potječu iz obalnih ležišta Baltičkog mora (Buršić-Matijašić 2003: 175). Pronađen je i ulomak ogrlice napravljene od brončane žice, vrlo sličan ogrlici s Vrčina, a tipičan za japodsko kulturno područje kasnog brončanog doba. Sličan nakit javlja se i na području Italije, u kasnobrončanodobnim nekropolama Desmonta di Veronella Fontanelle Mantovane ( Buršić-Matijašić 2003: 175). Grob datiramo u kasno brončano doba, a pripada skupini vrčinskih grobova, što nije ni čudno zbog blizine dvaju nalazišta, a i ostale sličnosti su neupitne, kao što je položaj u skupini na manje istaknutoj poziciji, pokojnik položen u zgrčenom položaju u sanduk od kamenih ploča, prilozi od jantara, a ističe se i nalaz ogrlice od spiralnih cjevčica, koja je datirana u kasnije brončano doba, kao i nekropola Vrčin (BuršićMatijašić 2003: 176).

\section{Vela Gromača kraj Kavrana}

Prilikom zemljanih radova 1972. godine za novu cestu kraj Kavrana otkriveno je nekoliko kamenih gromača, od kojih se najznačajnija, poznata pod nazivom Vela Gromača, nalazila na uzvisini povećeg platoa. Prvim istraživanjem tumula nađeni su ulomci keramike i neoštećeni grob (Baćić 1973: 8).

Grob koji se nalazio u tumulu bio je smješten četiri metra južno od središta. Konstrukcija kamene grobnice nije ostala sačuvana u cijelosti. Ploča koja je zatvarala grob na zapadnoj strani i sjeverna stijena groba sačinjena od malih kamenih pločica ostale su očuvane. Orijentacija groba bila je zapad - istok. U grobnici su pronađene oštećene kosti lubanje, ruku i nogu te crna zemlja s kamenjem, na kojima se vide tragovi paljenja. Podloga grobnice bila je živa stijena. U okolici groba pronađeni su ulomci keramike koje Baćić datira u rano brončano doba te izdvaja jedan ulomak ručke s pločicom - diskom, koju s posudom povezuje držak proširen prema dolje, što je karakterističan nalaz na istarskim gradinama u rano brončano doba. Ističe i ulomak ručke s vertikalno probušenom manjom okruglastom rupicom, koja osim po obliku i strukturom podsjeća na eneolitske ručke pronađene na Velikom Brijunu (Baćić 1973: 9-10).

Ispod brončanog tumula otkriven je neolitski sloj. Analizom ostataka keramike kulture impresso utvrđeno je da nalazište pripada drugoj fazi starijeg neolitika (Baćić 1973: 15). 


\section{Monkodonja}

Na gradini Monkodonja kraj Rovinja nađeni su ukopi na tri položaja: kameni tumuli koji su bili udaljeni od naselja, grobovi koji su bili smješteni na ulazu u naselje te jednostavni ukopi unutar naselja (Hänsel et al. 2009: 95).

Grob nazvan grob B, koji je vjerojatno i najstariji grob na Monkodonji, nalazio se kod ulaza u naselje na mjestu kule ili nekog sličnog fortifikacijskog objekta, unutar četvrtastog zatvorenog prostora veličine $3 \times 4$ metra. U grobu su nađene kosti novorođenčeta i odrasle ženske osobe. Kosti novorođenčeta datirane su između 2054. i 1937. god. pr. Kr., a kosti odrasle osobe između 1521. i 1428. god. pr. Kr. Smatra se da je grob nastao prije izrade bedema. Zanimljivo je da je ostao sačuvan te da je zapravo diktirao pravac pružanja fortifikacije (Hänsel et al. 2009: 96). Prilikom istraživanja groba otkriveno je da je dno groba bilo posuto slojem crvene zemlje dopremljene s drugog mjesta. Kosti novorođenčeta bile su sklonjene uz rub da bi napravile mjesto posmrtnim ostacima odrasle ženske osobe. Posmrtni ostaci pokojnice nisu ležali u pravilnom anatomskom rasporedu te se smatra da je preminula ženska osoba bila izložena prirodnom procesu raspadanja. Pronađena je i grobna stela koja se nalazila ispod urušene kule te je zajedno sa škrinjom i tumulom imala funkciju memorijalnog spomenika. Nakon podizanja bedema i ulaza, grob je ostao ukomponiran u objekt i očuvan. Tada je vjerojatno i sagrađena posebna prostorija za grob koja nije imala ulaz. Preminuli su zasigurno bili dio zajednice koja je naseljavala Monkodonju, a mjesto njihova ukopa ukazuje na njihov poseban status među stanovništvom (Hänsel et al. 2009: 99-104).

U blizini se nalazi i grob A, koji je također bio ukomponiran u obrambenu arhitekturu naselja. Smješten sa sjeverne strane zapadnog ulaza, koji je bio nadograđen u više faza, prvo je izoliran lučnim zidom, a kasnije u potpunosti prekriven proširenjem zida. Grob A

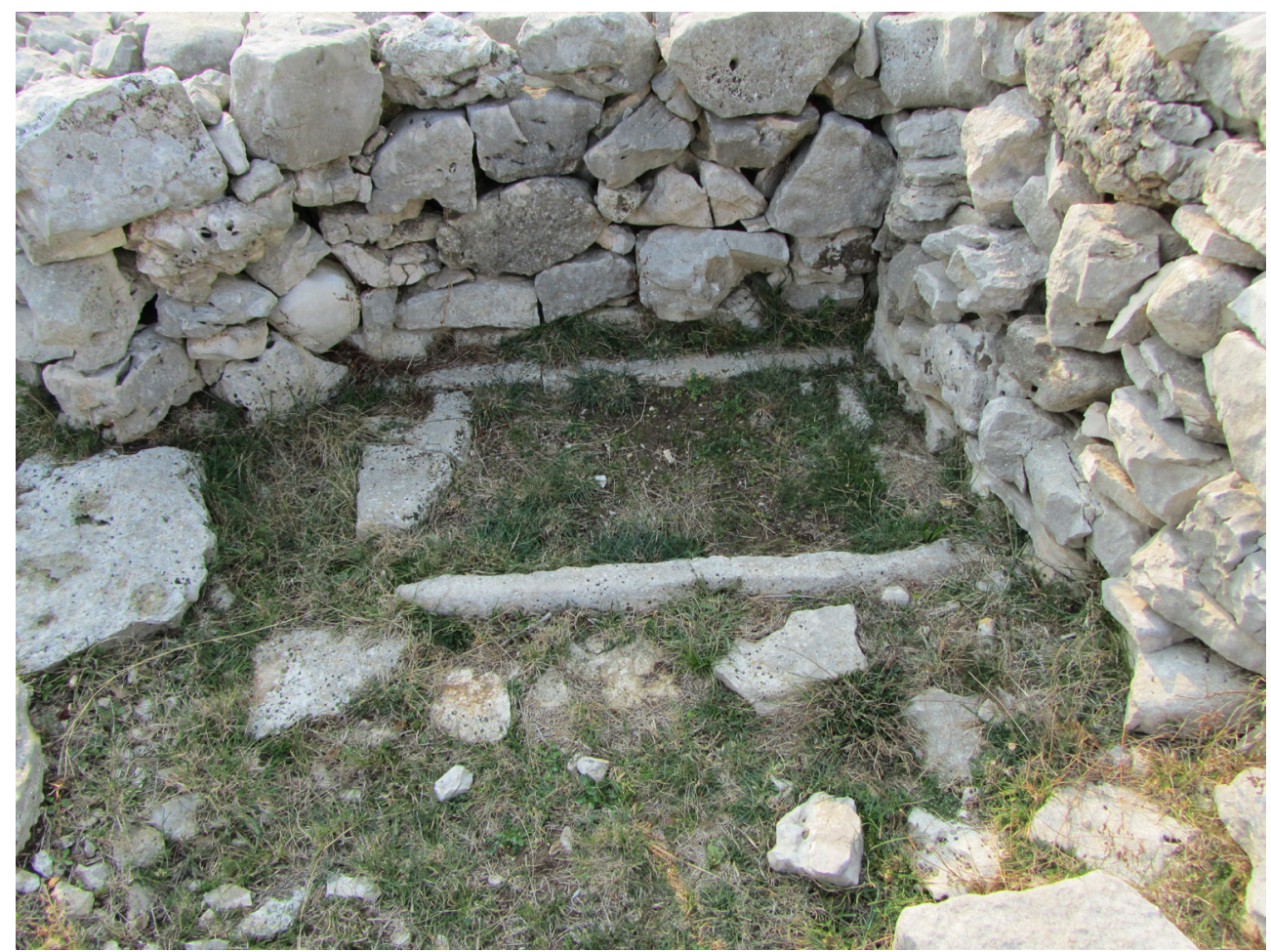

SI. 4: Monkodonja - grob A (snimila Hana Žerić, ožujak 2012.) 
je također bio sačinjen od škrinje, ali nije imao kamenu gomilu oko sebe. Uz ploču koja je zatvarala škrinju, nađena je još jedna tanja ploča koja je vjerojatno služila kao stela. U samom grobu nalazile su se kosti 10 do 15 osoba, najvjerojatnije ukopanih u različitim intervalima, pri čemu su starije kosti pomaknute. Sigurno je da su najmlađi posmrtni ostaci ukopani parcijalno. Pronađeno je pet lubanja, dok ostataka gornjih i donjih dijelova tijela ima trostruko više. Uz kosti su pronađeni ostaci keramike, bronce, spiralnih alkica te nekoliko sitnih perla od jantara i plavog stakla (Hänsel et al. 2009: 105-110).

U samom naselju pronađena je jama i nekoliko izgrađenih konstrukcija, za koje se pretpostavlja da su to ispražnjeni grobovi. Istočno od groba A pronađena je jama izdubljena u prirodnoj stijeni. Bila je ispunjena crnom zemljom i malim kamenjem. U njoj je pronađen ulomak kosti gornje vilice. Jama je bila smještena uz unutarnju stranu zida koji pokriva grob A, međutim, pretpostavlja se da je bila starija od groba A. Pronađena je i tanka kamena ploča koja je mogla služiti kao ploča preklopnica. Budući da se iznad jame nalazio veći sloj kamenja i dio urušenog zida pretpostavljamo da se uništavanje nije dogodilo recentnim djelovanjem (Hänsel et al. 2009: 113-114).

Grobovi na Monkodonji daju naslutiti da je na gradini postajao vodeći sloj stanovništva koji su svoje pokojnike pokapali na samom ulazu u naselje s ulogom očuvanja naselja od svih vrsta nedaća (Hänsel et al. 2009: 116-117).

\section{Mušego}

Na brdu Mušego, koji se nalazi s jugoistočne strane Monkodonje, pronađena je grupa od pet tumula, s po dva do četiri tumula (Hänsel et al. 2009: 92). Tumuli promjera 11 metara okruženi su suhozidom i tako tvore uređeno groblje, a koristili su se kroz nekoliko faza. Široke

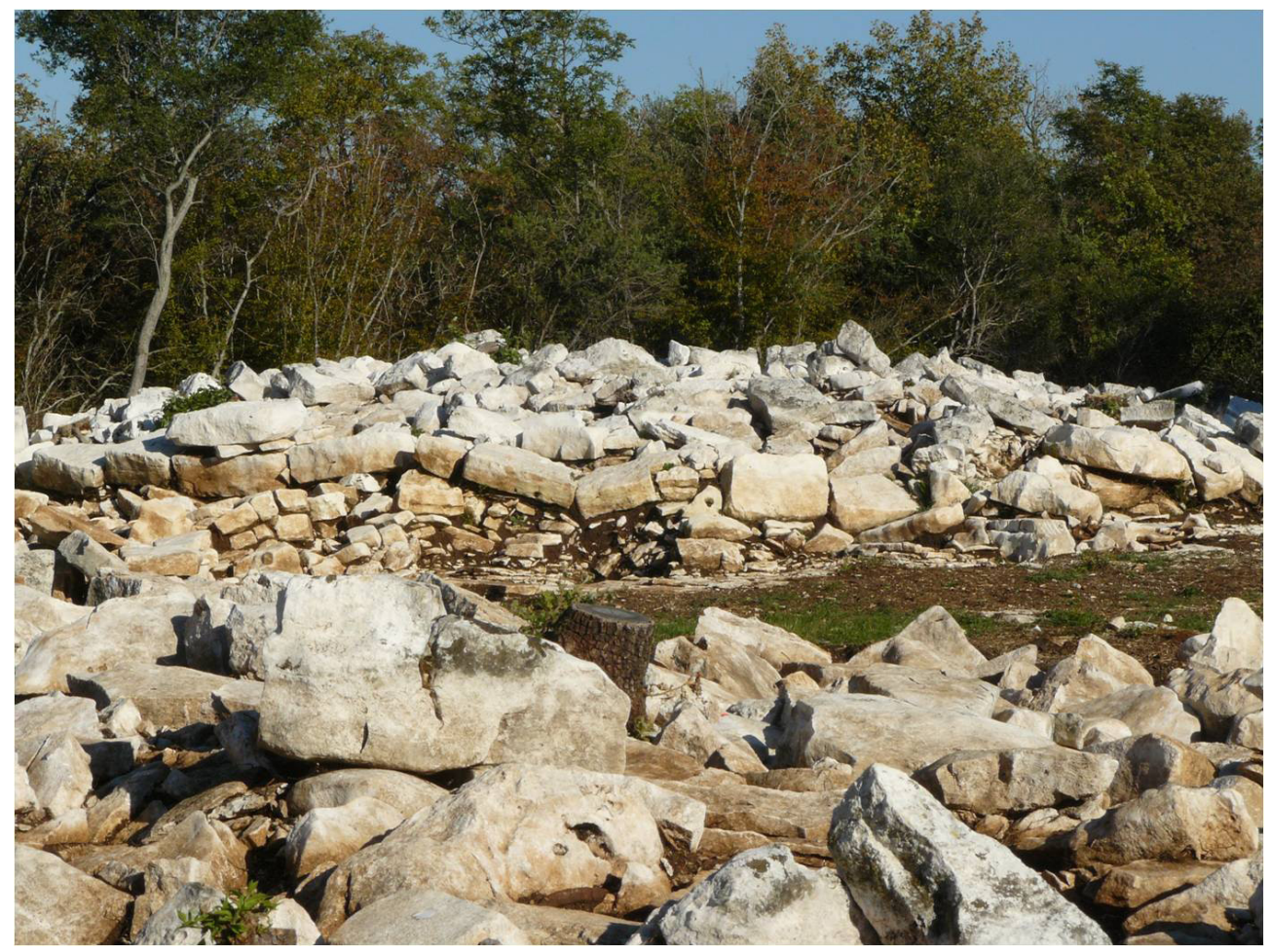

SI. 5: Mušego (snimila Hana Žerić, listopad 2007.) 
rampe vodile su do grobne škrinje. U grobovima su pronađene kosti više pokojnika za koje se smatra da su sekundarno pokopani. Kao grobni prilozi pronađen je nakit od tanke brončane žice te jantarne perle i perle od fajanse (Mihovilić et al. 2009: 50). Unutrašnjost tumula bila je ispunjena blokovima slaganim kružno od škrinje prema kružnom zidu. Na Monkodonji su pronađene samo dvije grobnice koje su pripadale visokom sloju društva. Vjerojatno su kameni tumuli na Mušegu bili grobovi vrlo važnih stanovnika poput onih s Monkodonje (Mihovilić et al. 2009: 112-117).

\section{Maklavun}

Na impozantnom položaju iznad mjesta Sošići na vrhu brda (kota 211.6) smješten je tumul Maklavun. lako mu već godinama prijeti ozbiljna devastacija zbog rada obližnjeg kamenoloma, istraživanja provedena 1957. i 1993. otkrivaju nam da su grob na Maklavunu okruživala tri koncentrična kruga kamenja. Prvi krug na uzvisini činio je pojas nabacanog kamenja oko grobnice. Vanjski zidni plašt činio je drugi koncentrični pojas koji je čuvao grobnicu od urušavanja. Najbolje je bio očuvan u svom južnom dijelu, gdje je dosezao visinu od 1,70 m. Treći pojas činio je unutrašnji zid, koji nije bio potpuno koncentričan s vanjskim pojasom (Baćić 1960: 200). Hänsel i Teržan smatraju da je Maklavum pripada tholosu grčko-egejskoga tipa, građenim tehnikom lažnog svoda. Neposredno u blizini pronađeno je trapezno lomljeno kamenje dimenzija 0,60-1,00 m, koji su bili potrebni za takav tehnički poduhvat. Osim toga, još se uvijek nazire dhromos - karakterističan ulaz u ovakav tip grobnica. Budući da su se najbliži primjeri ovakvih građevina nalazili jedino na samom jugu kontinenta, autori smatraju da tholos sliči onima mikensko-egejskog tipa, što i potvrđuje nalaz keramike koja pripada kasnoj fazi ranog brončanog doba ili srednje brončanom dobu

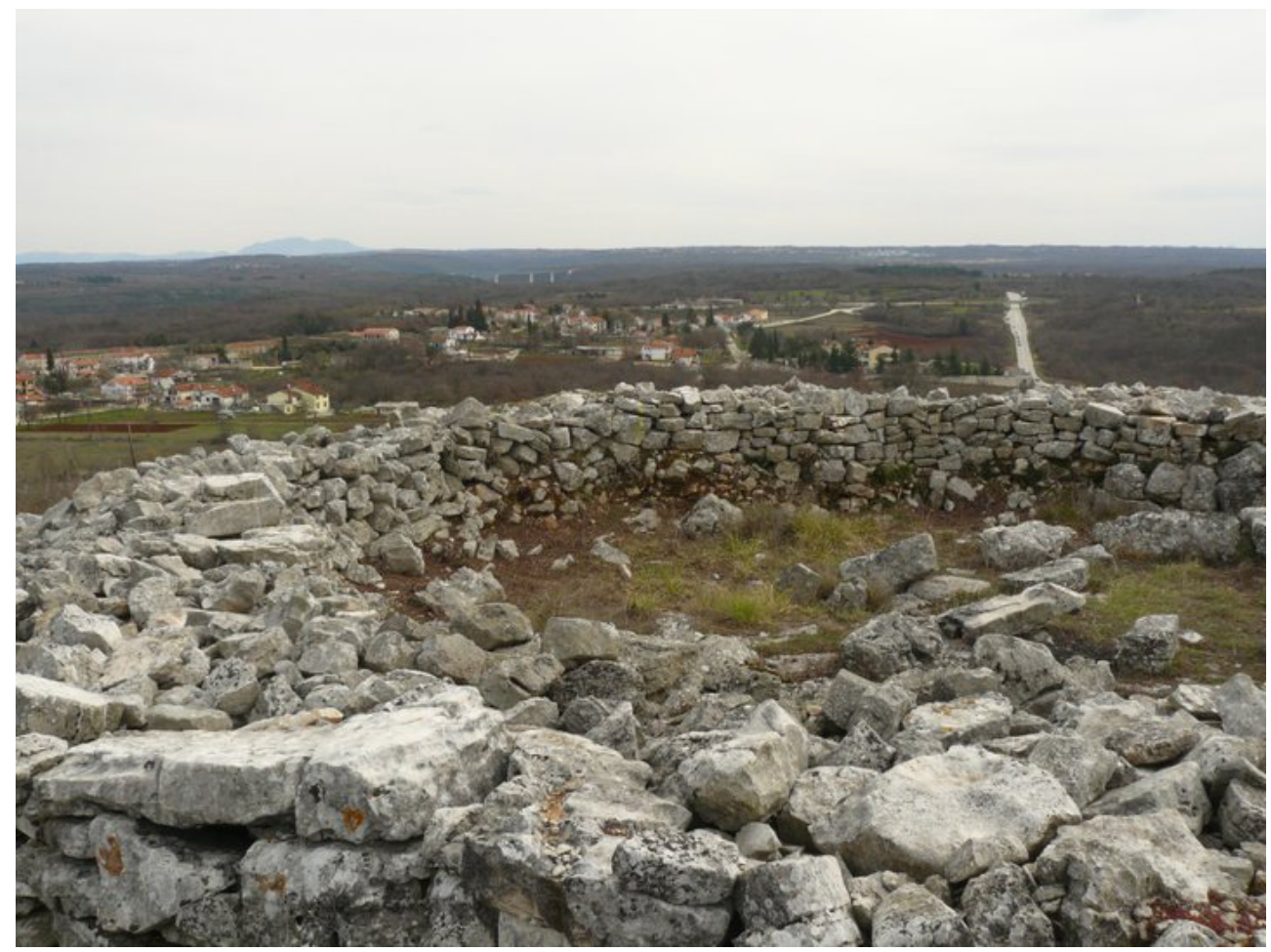

SI. 6.: Maklavun (snimila Hana Žerić, ožujak 2007.) 
srednjoeuropske terminologije, što odgovara srednjoj i kasno mikenskoj epohi u Grčkoj (Hänsel et al. 2001: 83). Grob se nije nalazio u sredini, već odmah iza prilaza u grobnicu, smješten u pravcu sjever - jug, a izrađen tehnikom suhozida. Izrađen tehnikom suhozida. Zid groba bio je odvojen od zida tumula desetak centimetara. U grobu su se nalazila tri pokojnika, dvije odrasle osobe te jedno dijete. Kosti su nađene u crnom sloju pepela koji se prostirao i iznad grobnice i prekrivao je preklopne ploče groba. U sredini tumula pronađena je brončano šilo sa slomljenim vrhom, a među pepelom ulomci keramike lokalne forme i više kosti konja i ptica. Od keramičkih predmeta ističe se posuda s laktasto oblikovanom ručkom i kružno zakošeno postavljenim dijelom, koja je karakteristična za srednjobrončano doba u Istri, što i omogućuje dataciju Maklavuna u to razdoblje. Ostali ulomci ne opovrgavaju tu dataciju (Hänsel et al. 2001: 88). Unutar prostora tumula pronađeni su i okomito postavljeni kameni blokovi koji su inače služili kao obrambeni sustav, među kojima se ističe veći četvrtasti kamen visine $80 \mathrm{~cm}$, za koji se pretpostavlja da je imao kultnu vrijednost. Okomito postavljeni kameni blokovi nađeni su i na susjednoj gradini Karaštak, koja je vjerojatno bila dom pokojnicima s Maklavuna (Baćić 1960: 201-202), što i potvrđuju nalazi keramike pronađeni prilikom izgradnje vodospreme koja se podudara u dataciji s onom pronađenom na Maklavunu (Hänsel et al. 2001: 84).

\section{Žamnjak}

Tri kilometra od Maklavuna nalazi se uzvisina Žamnjak na kojoj je istražen brončanodobni grob. Dimenzije tumula prije iskopavanja bile su: visina $2 \mathrm{~m}$, a promjer $13 \mathrm{~m}$. Kružni zid oko gomile bio je sastavljen od vertikalno postavljenog kamenja. U visini kružnog rubnog zida, unutar njega nalazio se ravan plato koji je nastao slaganjem većeg kamenja prirodno ravnih

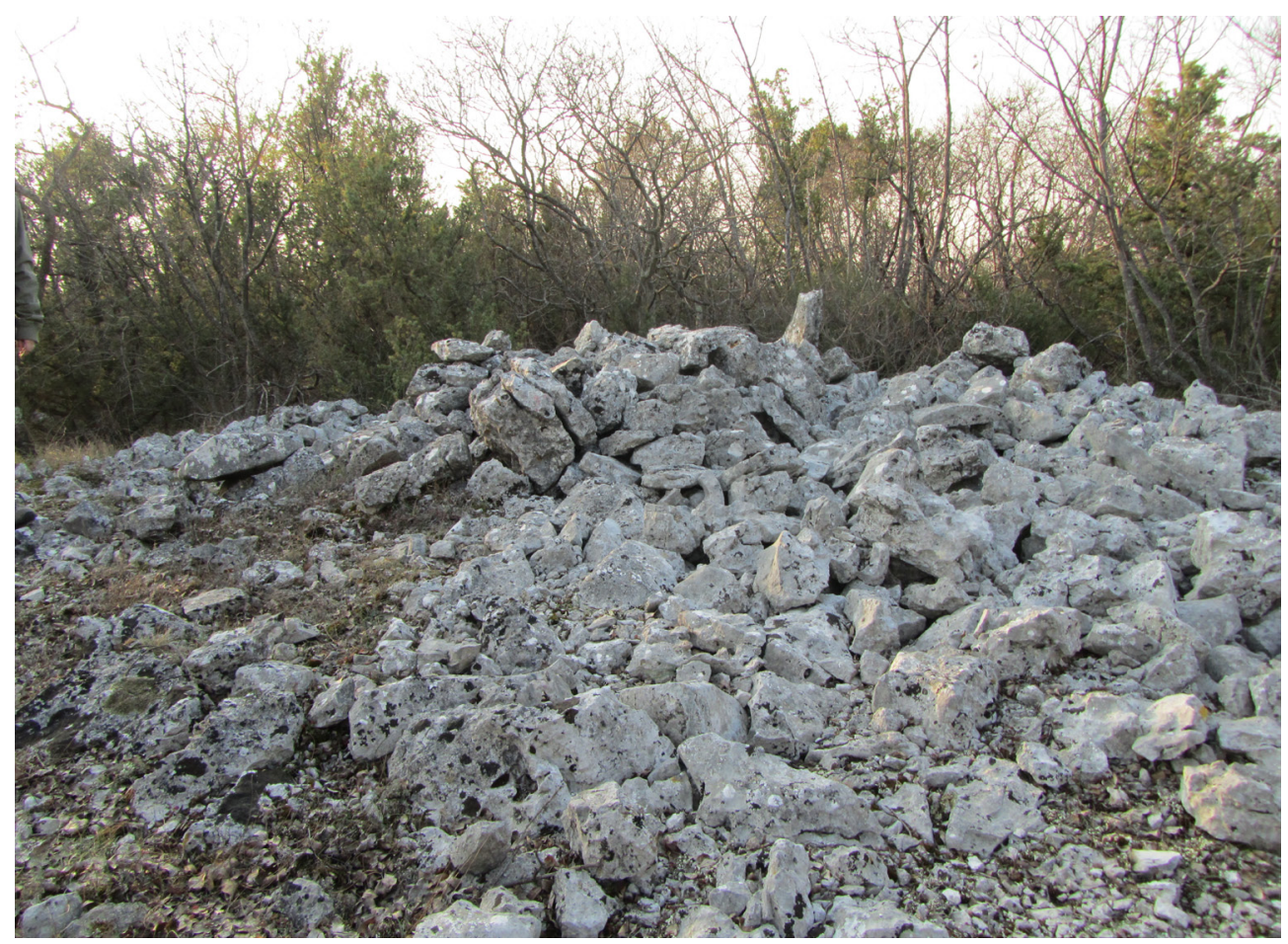

SI. 7: Žamnjak (snimila Hana Žerić, ožujak 2012.) 
ploha. U sredini tumula nalazila se grobnica sastavljena od šest kamenih ploča. Dimenzija groba bila je $225 \times 70 \mathrm{~cm}$. Manje bočne ploče bile su uvučene prema sredini grobnice tako da je unutarnja dužina groba bila samo jedan metar. Dno groba prekrivali su mali morski kamenčići. Slabo sačuvane kosti dviju odraslih osoba i jednog djeteta bile su prekrivene zemljom. Smatra se da ukopi nisu bili istovremeni, već naknadni. U grobu su pronađeni dijelovi spiralne brončane ogrlice i dvije jantarne perlice. Uz grob je pronađena i zdjela s četiri drške koje su jedna nasuprot druge povezane preko niskog vrata (Baćić 1960: 198-199). Pretpostavlja se da posuda nalikuje posudama iz Podunavlja koje pripadaju moriškoj kulturi (Čović 1983: 131).

\section{Vrčin}

Impozantna gradina Vrčin nalazi se sjeveroistočno od Vodnjana. Prvi ju je zabilježio Carlo Marchesetti, a istraživali su je R. Battaglia i Bruna Forlati Tamaro 20-ih godina prošlog stoljeća. Gradina Vrčin bila je naseljena još od starijeg neolitika, eneolitika do brončanog doba, kada nastaje utvrđeno naselje. Iz kasnog brončanog doba potječe i istražena nekropola, smještena uz ulaz pored bedema. Nekropola je svakako smještena namjerno uz ulaz u grad i vjerojatno je služila kao duhovna zaštita. Broj pronađenih grobova u literaturi je različit, varira od 17 do 20 (Buršić-Matijašić 1989: 478). Grobni sanduci bili su načinjeni od kamenih ploča. U svakom grobu pronađeno je po nekoliko ukopa (3-4), a najviše se u grobu nalazilo sedam ukopa. Prilikom novog ukopa kosti prijašnjeg pokojnika bile se grupirane na kraju grobnice. Pokojnici su bili polagani u sjedećem položaju u pravcu sjever-jug ili jug-sjever (Buršić-Matijašić 1989: 486). Postoje indicije da su pokojnici bili omotani u platnene ovoje (Buršić-Matijašić 2007: 536). Na Vrčinu je pronađena i ljudska lubanja na kojoj je vidljivo da se za života bolesnika vršila trepanacija. Pojedinačni grobovi ograđeni su niskim zidom (Buršić-Matijašić 1989: 478), dok su skupine grobova ograđene većim suhozidnim ogradama, tvoreći obiteljska grobna polja (Dimitrijević et al. 1998: 192). Od grobnih priloga pronađen je raznovrsni nakit: lančići, privjesci, prstenje, naušnice, napravljeni od brončane žice. Uz brončanodobni nakit na Vrčinu je pronađen i najveći broj jantarnih perlica u Istri, 40-ak perlica raznih veličina (promjera 0.7 $2.4 \mathrm{~cm}$ ). Boje perlica kreću se od svijetložute do smeđe varijante. Oblici su im također različitih nepravilnih i pravilnih oblika; okrugli, cilindrični, lećasti... (Buršić-Matijašić 1989: 483-484).

\section{Novi Grad kraj Krmeda}

Kraj mjesta Krmed nalaze se dva sedlasto spojena brežuljka pod nazivom Stari i Novi Grad. Stari Grad predstavlja dobro očuvano gradinsko naselje (Buršić-Matijašić 2007: 217), dok se na susjednom, Novom Gradu nalaze gromače (promjera 12-18 m i visine 0.50-2m). Prilikom arheološkog pregleda tumula otkriven je brončanodobni grob koji je bio postavljen u smjeru sjever-jug (Baćić 1954: 19). Grob se nije nalazio u središtu tumula, već sa strane, a oko tumula vidljiv je i suhozid napravljen od većih kamenih blokova (Baćić 1954: 22). Grob je bio sastavljen od pet kamenih ploča, a njegove dimenzije bile su: dužina $170 \mathrm{~cm}$ i širina $48 \mathrm{~cm}$ i visine $80 \mathrm{~cm}$. Grob nije bio ukopan u zemlju, već se nalazio na površini. Dno groba činila je kamena ploča koja je bila masivnija od ostalih. Ona je bila umetnuta u grob tako da pobočne ploče nisu ležale na njoj, kao što je to čest slučaj u drugim grobovima u Istri. Kako bi bila što stabilnija, grobnicu je podupiralo kamenje i s vanjske strane. Tako je pobočne ploče podupiralo poslagano kamenje, dok su uže kamene ploče podupirale kvadratne ploče složene jedna na drugu (Baćić 1954: 19). 


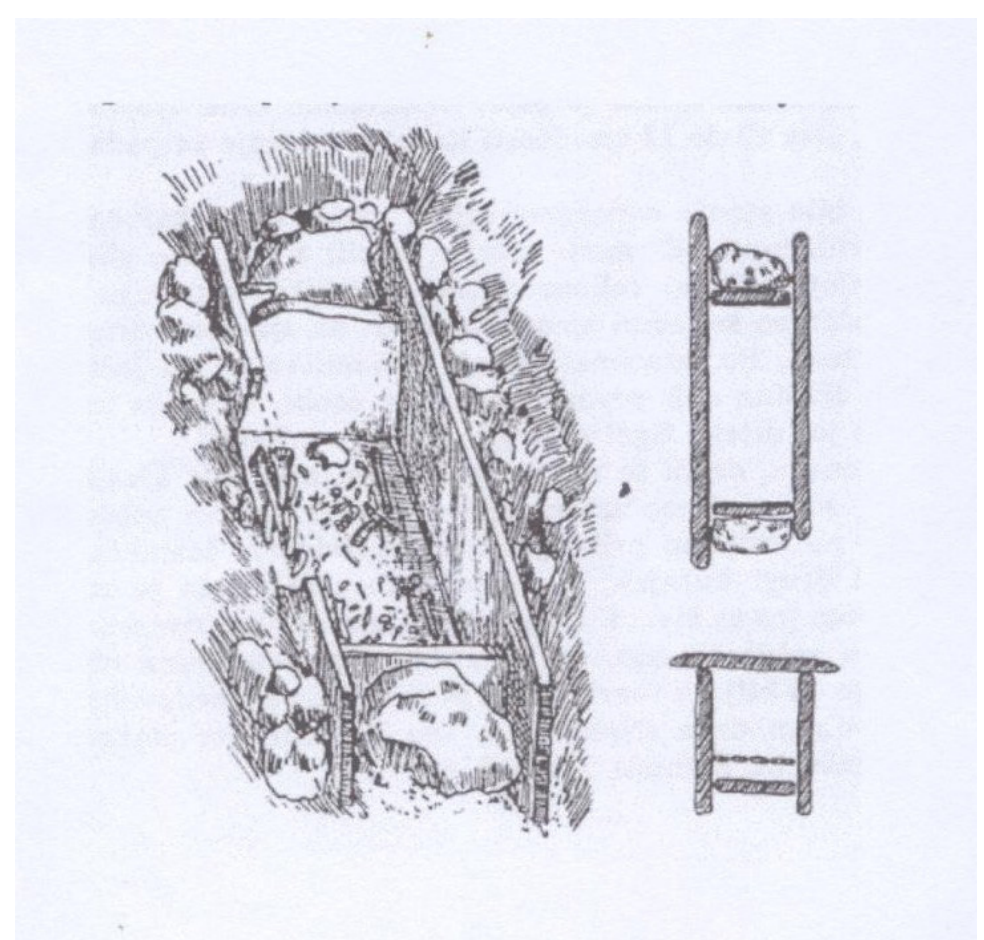

\section{SI. 8: Krmedski Novi Grad (Baćić 1954-1957)}

Iskopavanjem prvog sloja do $45 \mathrm{~cm}$ u grobnici među kamenjem, na južnoj strani, nađeni su dijelovi posude, fibule, dno zemljanog lončića i nekoliko košćica, dok je u sredini groba pronađena bedrena kost. $U$ sjevernom dijelu nalazilo se pravilno popločenje. $U$ drugom sloju koji se nalazio na dubini od $65 \mathrm{~cm}$ nađene su kosti prekrivene slojem zemlje. Takvo stanje groba govori nam da je ovo bio skupni grob u kojem je došlo do kasnijeg ukopa u istu grobnicu. Kosturi pokojnika koji su se nalazili na dnu nisu se micali prilikom kasnijeg ukopa, već su ostali netaknuti i prekriveni kamenim pločama. U sjevernom dijelu groba složeno kamenje smanjilo je volumen novog groba, i tamo je bio smješten pokojnik u sjedećem skvrčenom položaju. Kao grobni prilog pred njim je bio lončić. U drugom dijelu groba ispod kamenih ploča, nalazila su se tri pokojnika. Na južnu stijenu groba smješten je jedan pokojnik u sjedećem položaju, a na sjeveru drugi. Na sjevernoj strani, ispred drugog pokojnika nalazio se, također, i treći kostur, koji je pripadao djetetu muškog spola. Kod pokojnika smještenog na južnoj strani bio je položen i kamen na kojem je sjedio. Kod skeleta dječaka nađeno je najviše grobnog priloga, dijelovi posude, koščice goluba ili kokoške te jantarna perla i dvije brončane spiralne naušnice ili sljepoočnice (Baćić 1954: 20-21).

\section{Pećina Laganiši}

Pećina Laganiši kao specifičan speleološki sistem nalazi se u općini Oprtalj na nadmorskoj visini od $395 \mathrm{~m}$, a udaljena je $350 \mathrm{~m}$ od sela Laganiši po kojem nosi ime. ${ }^{2} \mathrm{U}$ jednom dijelu bio je prostor za "žive" a u drugom za "mrtve". Istraživanjima u prostorima na koje je podijeljena pećina pronađeni su brojni nalazi koji ukazuju na život u spilji kroz četiri razdoblja: u neolitiku, u kasnom bakrenom dobu, brončanom dobu i antici. Najbrojniji nalazi su upravo iz brončanog

Prva amaterska istraživanja trajala su od 2004. do 2006. (Komšo 2008: 8). 
doba: jedan tronožac i keramička posuda s bradavicom u unutrašnjosti koja se koristila za preradu mlijeka. Taj nalaz upućuje nas o djelatnosti tadašnjih obitavaoca pećine koji su se bavili stočarstvom i preradom mlijeka, prilikom sezonskog korištenja (Komšo 2008: 5 -15).

Mjesto ukopa nalazilo se na drugoj strani spilje u koju vodi uzak prolaz. Dužina prostorije je $11 \mathrm{~m}$, a širina $4 \mathrm{~m}$. Prostorija s ostatcima pokojnika bila je odvojena od ostalih prostorija suhozidom. Pod pećine bio je prekriven kamenjem i slojem sigovine, gdje su otkriveni brončani bodež, strjelica te brončana sjekira (Mihovilić 2008: 46). Ispod sige debljine 1-15 cm pronađeni su i ostaci pokojnika. Kosti preminulih bile su razbacane po prostoriji pa se smatra da pokojnici nisu bili pokopani, već položeni u prostoriju. Uz ostatke 12 pokojnika pronađeni su: sjekira, nož i strjelica, brončani prsten od brončanih traka te jantarne perle. Arheološke i antropološke analize ukazuju da je nekropola bila u funkciji tijekom 13.-12. st. pr. Kr. (Rajić Šikanjić 2009: 40).

\section{Zabilježeni i devastirani tumuli}

Pored navedenih istraženih ili djelomično istraženih nalazišta do danas je u Istri evidentiran veći broj mogućih ukopa. Uz navedene i opisane ukope, u kasnijim recima zabilježeni i oni koji su devastirani u potpunosti, dok je neke od njih prekrio zub vremena te danas nisu više vidljivi.

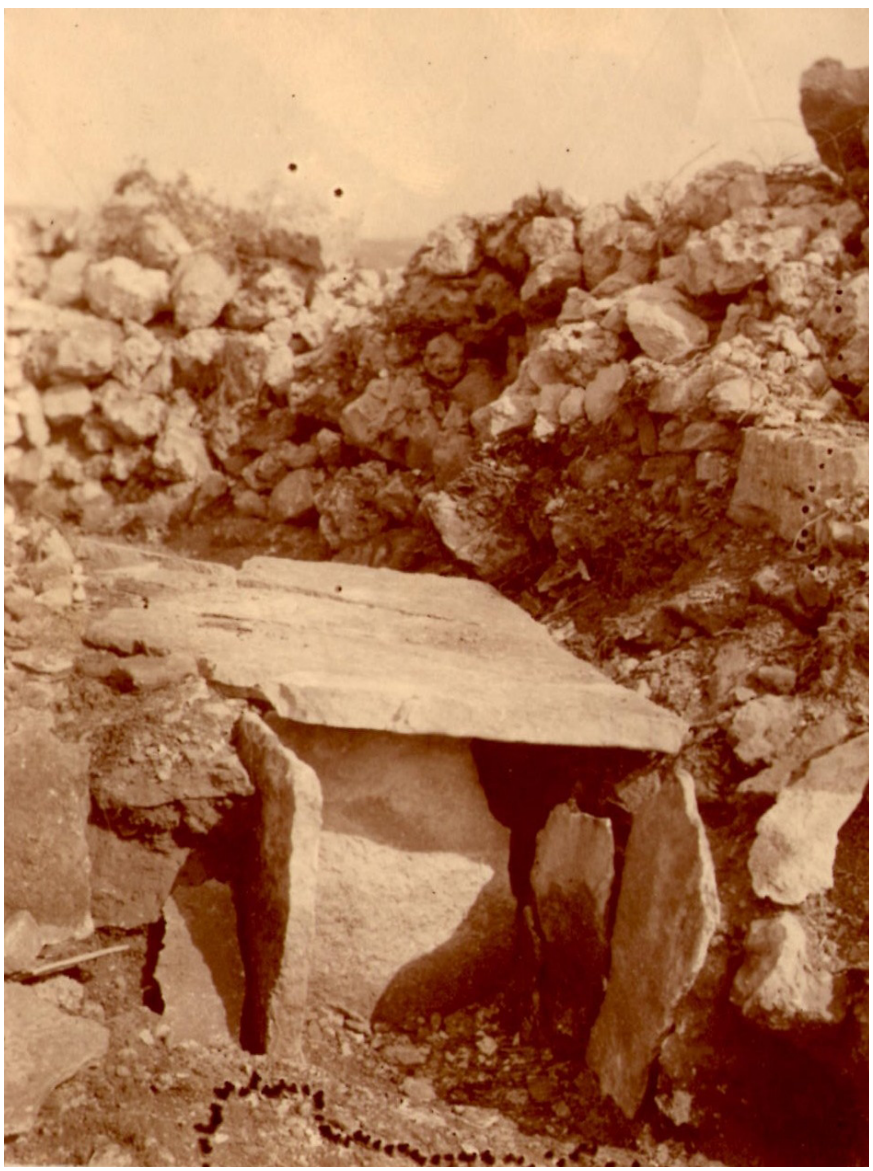

SI. 9: Tumul na Bombištu, album fotografija "Pola im krieg 1914-1918" K.u.k. Festungsartilleriebataillon Nr. 6, Grafička zbirka Sveučilišne knjižnice u Puli, str. 115. 
Jedan od većih tumula nalazio se na lokalitetu Val Marin u blizini Pule. Istraživanje se provodilo 1909. te je utvrđeno da je tumul iz ranog brončanog doba. U tumulu se nalazio sanduk od kamenih ploča, a dno grobnog sanduka činio je šljunak (Čović 1983: 118). Unutrašnja dužina groba bila je $120 \mathrm{~cm}$, dok je promjer tumula iznosio $30 \mathrm{~m}$. U tumulu je pronađen i brončanodobni nož, čija je oštrica duga 17,5 cm, koji pripada istočnomediteranskom, odnosno egejskom tipu ranobrončanih bodeža (Čović 1983: 118; Ruaro Loseri 1983: 128). Nekoliko godina kasnije istražen je i tumul na Bombištu u Banjolama. Smješten na impozantnom mjestu, ovaj je grob također datiran u rano brončano doba (Čović 1983: 118) i u njemu je nađen bodež egejskog tipa (Ruaro Loseri 1983: 128). U oba tumula grobnica je bila postavljena u smjeru istok - zapad (Buršić-Matijašić 2003: 178). U tim prvim istraživanjima na istarskom poluotoku, Gnirs je između 1900. i 1905. otkrio i lokalitet Paravia kraj Barbarige, gdje je zabilježio nekoliko tumula, od kojih je neke i istražio. Tumul I bio je visine $2 \mathrm{~m}$ i promjera oko $10 \mathrm{~m}$. U sredini gromače nalazio se grobni sanduk napravljen od kamenih ploča. Širina groba bila je 0,5 m, dok je vanjska dužina iznosila $1,50 \mathrm{~m}$, a visina 0,65 m. U drugom tumulu otkrivena je grobnica dužine 1,20 širine $0,67 \mathrm{~m}$ i visine $0,70 \mathrm{~m}$. Grobni sanduci oba tumula bili su smješteni u pravcu sjever - jug (Gnirs 1906: 21). Djelomično je istražen i jedan od tumula otkrivenih na području Vetve, na pićanskoj strani Raške drage. Promjer tumula bio je $12 \mathrm{~m}$, a visina 0,60 m. U tumulu se nalazio grobni sanduk napravljen od tankih ploča vapnenca. Sanduk je bio popunjen glinom, a na nju polegnut pokojnik u zgrčenom položaju. Grob je bio orijentiran prema sjeveru. Pronađene su samo nožne kosti pokojnika. Nekoliko desetaka metara dalje nalazio se drugi tumul koji je sadržavao jednaku konstrukciju, međutim, u vrijeme dolaska arheologa već je bio devastiran te ga se nije moglo istražiti (Mihovilić 1989: 73).

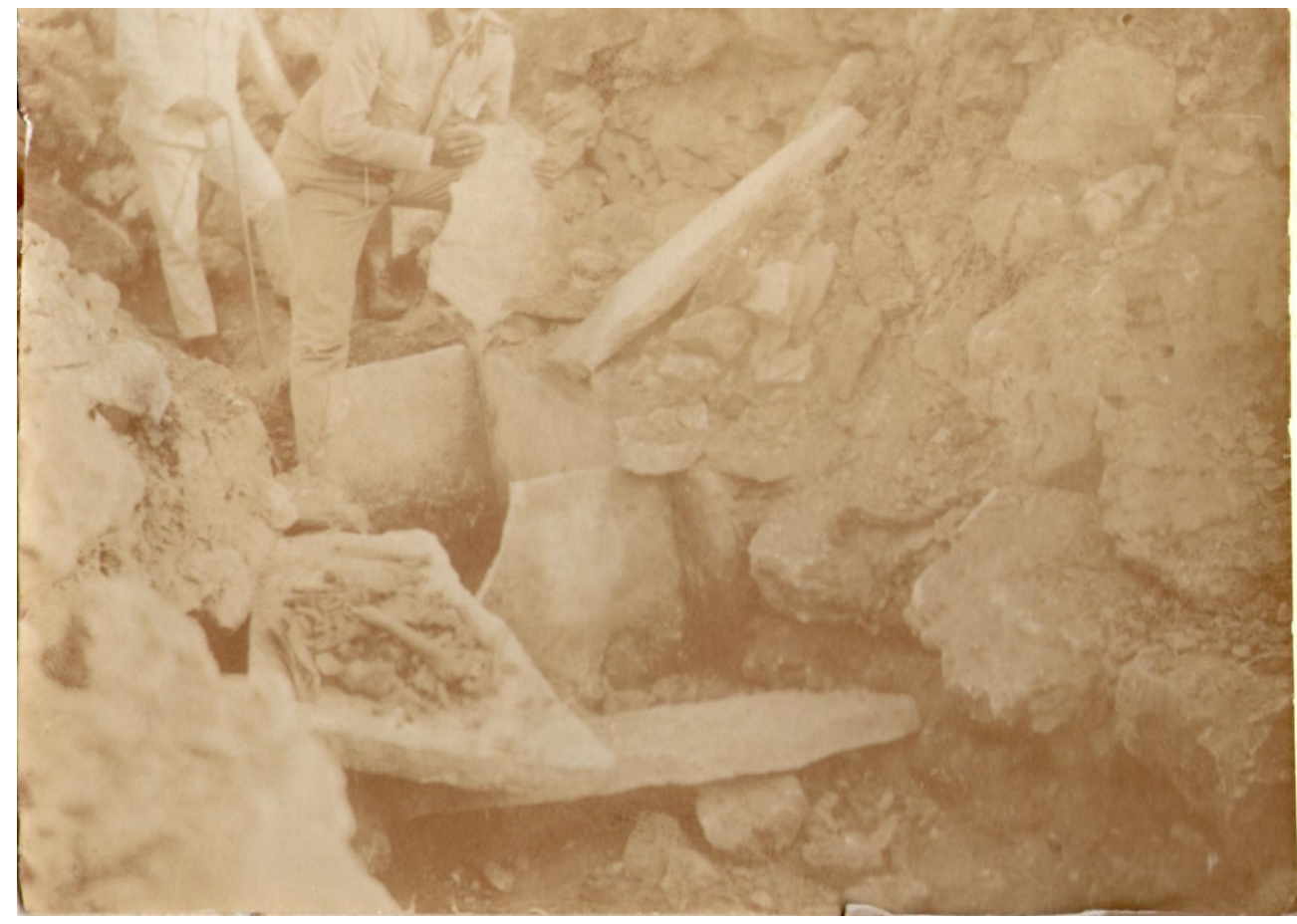

SI 10: Devastirani grob na Bombištu s vidljivim ostacima kostiju, album fotografija "Pola im krieg 1914-1918” K.u.k. Festungsartilleriebataillon Nr. 6, Grafička zbirka Sveučilišne knjižnice u Puli, str. 115. 
Tabela 1. - Istraženi brončanodobni ukopi

\begin{tabular}{|l|l|l|l|}
\hline IME & $\begin{array}{l}\text { KATASTARSKA } \\
\text { OPĆINA }\end{array}$ & LITERATURA & OPIS \\
\hline Gomila & Premantura & $\begin{array}{l}\text { Marchesetti 1903: } \\
104 \\
\text { Shiavuzzi 1911: 161 }\end{array}$ & $\begin{array}{l}\text { Veliki grobni tumul u kojem je 1898. } \\
\text { prilikom istraživanja otkriven kameni } \\
\text { sanduk s ostacima pokojnika u vrlo } \\
\text { lošem stanju. }\end{array}$ \\
\hline Krnički porat & Krnica & Baćić 1971 & $\begin{array}{l}\text { Na dnu krničke luke nalazi se tumul } \\
\text { koji je istražen 1978. godine. }\end{array}$ \\
\hline Sv. Duh & Novigrad & $\begin{array}{l}\text { Marchesetti } \\
1892: 255\end{array}$ & $\begin{array}{l}\text { Marchesetti je pronašao oko stotinjak } \\
\text { tumula oko gradine Sv. Duh od 1889. } \\
\text { - 1891. od kojih je istražio 15. }\end{array}$ \\
\hline Monter & Rovinj & Baćić 1977 & $\begin{array}{l}\text { Djelomično istražen tumul. } \\
\text { Na uzvisini Fratuca, sjevernije od } \\
\text { gradine Monter, 1977. istražen je } \\
\text { devastirani tumul. Pronađene su kosti } \\
\text { pokojnika položene u sjedeći položaj. } \\
\text { Orijentacija groba bila je istok - } \\
\text { zapad. }\end{array}$ \\
\hline
\end{tabular}

Istraženi ukopi samo su mali dio brončanodobne istarske slagalice, puno je više tumula koji su evidentirani i zabilježeni, ali ne i istraženi. Takav je i impozantni tumul Maškerada (177 $\mathrm{m} / \mathrm{nv}$ ), na prostoru između Gajane i Bala u blizini gradina Turnina, Mažin i Sv. Mihovil. Prema Borisu Baćiću, uzvisina Maškerada predstavlja gradinu koju on datira u brončano doba, no vjerojatnije je da je to ipak brončanodobni tumul okružen koncentričnim terasama širine 20 i 10 metara i suhozidima. Tumul nije nikad istraživan, a svojom veličinom i položajem "odražava ugled i društveni položaj sahranjene ličnosti" (Buršić-Matijašić 2002: 85-95). Iz zračnih snimaka vidljiv je put u spiralnom usponu. Takav spiralni oblik puta upućuje na razmišljanje o tome je li Maškerada samo grobni tumul ili je možda riječ o kultnom mjestu. Slični obredi zablježeni su na tumulima Žamnjak i Maklavun (Buršić-Matijašić 2002: 85-95).

\section{Grobni prilozi}

Kada govorimo o grobnim prilozima važno je razlikovati opremu pokojnika i grobne priloge. Oprema pokojnika najčešće je dio nošnje ili osobni nakit, dok grobni prilozi podrazumijevaju oružje, oruđe, posuđe, hranu, piće, obredne posude za libacije i žrtve paljenice. Pomoću njihovih tipoloških obilježja određuje se kojoj je kulturnoj zajednici pripadao pokojnik, kao i razdoblje iz kojeg potječe. Količina i vrsta grobnih priloga otkrivaju mnogo o pokojniku, od spola i zanimanja do društvenog položaja (Težak-Gregl 2011: 160).

Prilozi pronađeni u istarskim brončanodobnim grobovima skromni su i malobrojni (Matijašić 2005: 16). Od oružja su nađena samo dva brončana bodeža egejskog tipa u grobovima na Bombištu i Valmarinu koji se datiraju u rano brončano doba (Ruaro Loseri

Podaci preuzeti iz knjige "Gradine Istre" te članka "Škicini - brončanodobni grob pod tumulom" autorice Klare Buršić-Matijašić. 
1983: 128). U grobovima iz kasnijih faza brončanog doba nije nađeno nikakvo oružje ni oruđe. $U$ većini istraženih istarskih tumula pronađeni su ulomci keramičkih posuda koje su najvjerojatnije bile razbijane tijekom izvođenja obreda prilikom ukopa. Kada govorimo o obredima izvršenim na istarskim tumulima, treba spomenuti i kosti domaćih životinja i ptice te sloj pepela pronađen unutar ozidanog unutrašnjeg vijenca u tumulu na Maklavunu (Čović 1983: 125). Nakit pronađen u grobovima brončanodobnih stanovnika Istre skroman je i jednostavan. Nakit je najčešće izrađen od bronce, međutim nađeni su i koštani i jantarni primjerci, a možemo ga podijeliti na nakit glave, ruku i odjeće. Najbogatije nalazište nakitom zasigurno je nekropola na Vrčinu, a dijelovi nakita pronađeni su još i u grobovima na Velikom Brijunu, Žamnjaku, Škicinima, Novom gradu kraj Krmeda, Monkodonji i Mušegu (BuršićMatijašić 1989: 475-494, Vitasović 2003: 55-108, Baćić 1954: 15-23, 1960: 197-202, Hänsel, et al. 2009: 81-122).

Pronađene narukvice Čović dijeli u dvije vrste, prva je pronađena na krmedskom Novom gradu, sačinjena je od uske vrpce čiji krajevi prelaze u dva spiralna diska. Slične narukvice koje datiraju iz brončanog doba pronađene su od Poljske do Ukrajine, i sjeverne Hrvatske. $\mathrm{U}$ kasno brončano doba nalazimo ih od sjeverne Europe preko Panonske nizine pa sve do Epira u Grčkoj (Čović 1983: 90). Drugoj vrsti pripada narukvica pronađena na Vrčinu, izrađena od valovite žice, a krajevi joj također prelaze u spiralu. Motiv spirale pojavljuje se i na naušnicama ili sljepoočničarkama koje su bile izrađene od dvostruko spiralno savijene žice. Nekima su krajevi prelazili u spiralni disk, dok su druge imale raskucani i zavinuti kraj. Pretpostavlja se da su neke od njih s malim promjerom služile i kao prstenje. Na Vrčinu su pronađeni i privjesci spiralno naočarastog izgleda (Batović 1983: 291-292).

Kao grobni prilog među nakitom javlja se i jantar. To je fosilizirana smola različitog porijekla, a od srednjeg brončanog doba nalazimo ga kao grobni prilog diljem Sredozemlja pa tako i u Istri (Bakarić 2006: 122). Jantar je u Istru dospijevao i kopnenim i morskim putovima. Jantarnu masu bilo je lako oblikovati, stoga jantarni ukrasi znaju biti raznih oblika koji su povezani uz magiju i život (Buršić-Matijašić 1995: 57). lako se Istra nalazila na sjecištu trgovačkih putova, moramo primijetiti siromašan broj brončanodobnih nalazišta jantara svega ih je šest. Najstarija datirana jantarna perla iz ranog brončanog doba pronađena je u grobnoj gomili na Žamnjaku u južnoj Istri. Mala lećasta perla promjera 1,0 cm i debljine 0,8 cm nalazila se na ogrlici od brončanih saltaleona (Buršić-Matijašić 1995: 57). Istom razdoblju pripadaju jantarne perle nađene u grobu u Škicinima. Najvjerojatnije su također bile sastavni dio brončane ogrlice (Buršić-Matijašić 2003: 175). Jantar pronađen na gradini Vrčin (BuršićMatijašić 1995: 69) potječe iz razdoblja koje je bilo nekoliko stoljeća kasnije (13. i 12. st. pr. Kr.). To je ujedno i najbogatije brončanodobno nalazište jantara u Istri, budući da je nađeno pedesetak zrna. Perle su različitih boja, oblika i promjera (Batović 1983: 29) te su u dva slučaja nanizane u ogrlicu. Jedna ogrlica ima 11 cilindričnih i okruglih perli crvenosmeđe boje. Drugi primjerak ima niz manjih pločastih i okruglih perli sa širokom rupom između kojih se nalaze i neobrađeni komadi jantara. Probušena jantarna perla nađena je i u grobu pod gomilom na Novom gradu kraj Krmeda (Batović 1983: 29), a kao grobni prilozi na brdu Mušegu kraj Monkodonje također su nađene jantarne perlice (Mihovilić et al. 2009: 50). Isto vrijeme nastanka pripisuje se i nađenim grobovima u samom naselju Monkodonja, gdje su u dva groba nađene sitne perlice jantara (Hänsel et al. 2009: 81-122). 


\section{Zaključak}

Brončano doba u Istri obilježilo je 2. tisućljeće pr. Kr. kada je bakrenodobno stanovništvo zamijenilo novopridošlo koje je započelo živjeti na utvrđenim uzvisinama - gradinama, ali i naseljima izvangradinskog tipa (Mihovilić 2009: 48) Uz tipičan način gradnje naselja, njihove su karakteristike poznavanje izrade brončanog oružja i oruđa te ratnički ustroj, no najpoznatiji su po izradama grobnica kružnog oblika koje su gradili, kao i svoja naselja, na vrhovima brda (Mihovilić 1986: 15-16).

Život na gradinama bio je dobro organiziran. Gornji grad bio je rezerviran za aristokraciju, dok su niže terase bile predviđene za ostalo stanovništvo koje se prvenstveno bavilo ratarstvom i stočarstvom. Zbog blizine mora, koje je omogućavalo ribolov, brončanodobni stanovnici Istre bavili su se i trgovinom. Njihove luke na istarskoj obali bile su na važnom trgovačkom putu koji je spajao Sredozemlje sa središnjom Europom (Mihovilić 2009: 29-30).

Arheolozi 20. st. koji su istraživali istarsko brončano doba najviše su saznanja o tadašnjem načinu života stekli upravo istražujući tumule. Posljednja prebivališta bile su kamene kružne gomile na vrhu brda ispod kojih se nalazio grobni sanduk, najčešće sačinjen od nekoliko kamenih ploča, dok se dno postavljalo sitnim morskim šljunkom. Pokojnik bi se polagao u ležećem ili zgrčenom položaju s različitim prilozima (Mihovilić 2009: 35).

Za vrijeme brončanog doba u Istri imamo nekoliko vrsta ukopa. U rano brončano doba novopridošli stanovnici pokapali su se pod tumulima. Najznačajniji su Valmarin i Bombište kraj Pule. Brončani bodeži pronađeni na tim lokacijama jedini su takvi primjeri do sada pronađeni u Istri i danas se čuvaju u Arheološkom muzeju u Puli (Čović 1983: 118). Po važnosti se ističu i dva tumula, vrlo blizu jedan drugoga, smješteni između Bala i Rovinjskog Sela, Maklavun i ̌̌amnjak. Maklavun je tumul u kojem su, osim ostatka pokojnika pronađeni i grobni prilozi: igla te kosti ptica, vjerojatno zbog obreda koji se izveo, ali o detaljima možemo samo naslućivati. Tumul na Žamnjaku važan je jer je u njemu pronađena keramička posuda $s$ " $x$ " drškom, koja upućuje na veze $s$ Podunavljem te najstarija jantarna perla na našem području (Baćić 1960: 197-202). Monkodonja, kao najistraženija gradina u Istri, posebna je i po jedinstvenom ukopu unutar bedema. Naime, u najstarijem grobu, koji datiramo u vrijeme izgradnje Monkodonje, nalaze se posmrtni ostaci osoba za koje se smatra da su bile od posebne važnosti za zajednicu. Njihov grob sačuvali su i sljedeće generacije te su ga ugradili u sustav bedema u kasnijoj fazi razvoja gradine. Slična situacija je i kod ostala dva groba koja su smještena uz ulaze. Na jednom ulazu kraj bastiona otkriveni su ostaci muškarca, dok su u drugom grobu otkriveni ostaci 10-15 pojedinaca, selektivno odabranih dijelova tijela, što je primjer parcijalnog ukopa. Treba istaći još jednu posebnost, a to je pokop između kuća na akropoli, što je do sada jedini zabilježeni primjer u Istri. Stanovnici Monkodonje svoje pokojnike pokapali su i na susjednom brežuljku Mušego. Tri velika tumula posebno su odvojena suhozidom od ostalog prostora, najvjerojatnije je svaki tumul bio grobnica jedne obitelji (Hänsel et al. 2009: 92-114), što je čista suprotnost od ravnih grobova bez tumula pronađenih na Magornjaku, Šandalji i Krmedu s kraja srednjeg brončanog doba (Baćić 1954: 15-23). U kasno brončano doba javljaju se ravne nekropole uz zidine gradina Vrčina i Brijuna, s time da se groblje na Vrčinu, s ukopom u sjedećem položaju smatra prvim klasičnim grobljem u Istri (Buršić-Matijašić 1989: 478). Postoji teorija da su i nezakcijski monumentalni spomenici iz istog razdoblja, budući da su izrade pojedinih pokrovnih ploča grobnica identične. Istražujući nezakcijske kamene spomenike, Josip Mladin iznio je tezu u kojoj te nalaze datira u kasno brončano doba nazivajući ih spomenicima "vrčinskog tipa". Naime, utori poklopca na grobnoj ploči sa spiralnim ukrasima vrlo su slični onima na ploči preklopnici s Vrčina, a dvije blok ploče koje izgledaju kao dovratnici podsjećaju na dijelove groba-kuće dolmenskog tipa koji se javljaju u nekim dijelovima Europe u brončano doba 
(Mladin 1966: 36-39). Leonida Kovač analizom simbola na kamenim spomenicima tvrdi da su motivi spirale, dvostruke spirale, svastike i meandra vrlo dobro poznati simboli u duhovnom životu Indoeuropljana. Autorica ističe da su motivi spirale kao simbola labirinta te dvostruke spirale kao simbola drva života i mjesečevih mijena poznati još u brončano doba (Kovač 1994: 47-48).

U pećini Laganiši u općini Oprtalj pronađen je jedini zabilježeni brončanodobni ukop u Istri koji nam pokazuje da su pećine u to doba služile ne samo za obitavanje, već kao mjesta ukopa. O kakvom je turbulentnom razdoblju kasnog brončanog doba riječ, najbolje nam svjedoče nalazi nađeni u pećini. Nalazište Laganiši bilo je posljednje prebivalište nekoliko starijih osoba i osmero djece mlađe dobi. Analizom kostiju utvrđeno je da su pokojnici vodili težak život, u kojem su siromaštvo i pomanjkanje osnovnih namirnica bile svakodnevnica. Pronađena keramika ukazuje na mogućnost da su stanovnici pećine pripadali novom stanovništvu koje će zamijeniti brončanodobno (Rajić Šikanjić 2009: 37-44).

Grobni prilozi pronađeni u brončanodobnim grobovima Istre skromni su i jednostavni. Najčešće se javljaju komadi nakita načinjenog od tanke brončane žice: lančići, naušnice i narukvice. Njihovi krajevi često prelaze u spirale i dvojne spirale koje simboliziraju stablo života. Kao ukras često su dodavane jantarne perle, za koje se smatra da su bile sastavni dio brončanodobnog duhovnog života (Mihovilić 2009: 36).

O svetištima nema puno podataka. Tholos Mali sveti Anđeo zasigurno je bio svetište. Na njemu su pronađeni predmeti koji su se koristili u prinošenju libacijske žrtve, keramička šalica sa šupljikavim dnom, keramički nož te životinjske kosti (Čović 1983: 125). Smatra se da je jama koja se nalazi u sastavu gradine Monkodonja, također imala kultna svojstva te da su pravilni oblici u kamenu bili tron nekog vladara Monkodonja, koji je s njega nadgledao obred. U samoj jami pronađeni su fragmenti keramike za koju se pretpostavlja da je bačena prilikom obreda (Mihovilić et al. 2001: 49).

Nažalost, tijekom svih proteklih stoljeća vrijeme i ljudska ruka devastirali su mnoga nalazišta pa tako i tumule. Od antike pa do novog vijeka ne postoje pisani izvori o prapovijesnim lokalitetima, međutim, od kraja 19. st. kada započinju prva istraživanja do današnjih dana primjećujemo da veliki broj tumula koje su zabilježili prvi istraživači više ne postoje. Kao i gradine, pojedini su tumuli tijekom vremena doživjeli devastaciju i danas o njima znamo iz arheoloških izvještaja. Neki su se stopili s krajolikom, zarasli u makiju, i otkriveni su tek nedavno, poput tumula u uvali Marić, te su sačuvali svoj oblik i formu. Najpoznatiji po devastaciji je brončanodobni grob Maklavun, koji je privukao pažnju javnosti kada je Ministarstvo kulture Republike Hrvatske na temelju prosvjednih pisanja javnosti zabranilo tamošnjem kamenolomu da se svojim radom približava granicama tumula. Zadnjih godina pokušava se senzibilizirati javnost za kulturnu vrijednost gradina pa tako i tumula. Pozitivan je primjer uređeni prapovijesni parkovi na Monkodonji i Mušegu, koji su počeli privlačiti posjetitelje. Istarski kažuni i suhozidi već su prepoznati kao kulturna blaga pa se možemo nadati da će i tumuli, koji su zajedno s njima tihi pratioci stanovništva u prostoru, biti prepoznati i da će, pored rimske i srednjovjekovne, i prapovijesna Istra naći svoje mjesto pod suncem kulturnopovijesnog pejzaža Istre.

Tumuli, spomenici anonimnih pojedinaca koji su bili štovani za života, a i nakon smrti, trebali bi barem iz civilizacijskih razloga biti poštivani i danas. To su grobovi ljudi koji su živjeli na ovom prostoru pod istom nebeskom kapom kao i mi, a naša je zadaća da sačuvamo te prastare spomenike naših prethodnika za buduće generacije. 


\section{POPIS LITERATURE}

\section{BAĆIĆ 1954}

Boris Baćić, "Novi grobovi iz brončanog doba u Istri", Vjesnik za arheologiju i Historiju Dalmatinsku, 56 - 58/2, Split 1954., 15-23.

\section{BAĆı́́ 1960}

Boris Baćić, "Tumuli iz brončanog doba na Maklavunu i Žamnjaku u južnoj Istre", Jadranski zbornik IV, Rijeka - Pula 1960., 197-202.

\section{BAĆIĆ 1970}

Boris Baćić, "Prilozi poznavanju prahistorijske gradinske fortifikacije u Istri", Adriatica praehistorica et antiqua Gregorio Novak dicata, Zagreb 1970., 215-227.

\section{BAĆIĆ 1973}

Boris Baćić, "Vela gromača kraj Kavrana", Histria archaeologica IV, svezak 1., Pula 1973., 7-15.

\section{BAKARIĆ 2006}

Lidija Bakarić, "Jantar", u: Trgovina i razmjena u pretpovijesti, Sanjin Mihelić (ur.), Arheološki muzej u Zagrebu, Zagreb 2006., 122 -126.

\section{BATOVIĆ 1983}

Šime Batović, "Kasno brončano doba na istočnom jadranskom primorju", Praistorija jugoslavenskih zemalja IV, Sarajevo 1983., 284-304.

\section{BENAC 1984}

Alojz Benac, Kult mrtvih na ilirskom području u praistorijskom dobu, Sarajevo 1984.

\section{BURŠIĆ-MATIJAŠıĆ 1989}

Klara Buršić-Matijašić, "Gradina Vrčin u okviru brončanog doba Istre", Arheološki vestnik 39 40, 1988 - 1989., Ljubljana 1989., 475- 494.

\section{BURŠIĆ-MATIJAŠIĆ 1995}

Klara Buršić-Matijašić, "Prapovijesni jantarni nakit s podučja Istre i Cresa", Histria archaeologica 20 - 21/1989/ 1990, Pula 1995., 55-77.

\section{BURŠIĆ-MATIJAŠIĆ 2002}

Klara Buršić-Matijašić, "Maškerada", Histria Antiqua 8/ 2002, Pula 2002., 85-94.

\section{BURŠIĆ-MATIJAŠIĆ 2003}

Klara Buršić-Matijašić, "Škicini (Vodnjan) bron- čanodobni grob pod tumulom", Opuscula Archaeologica 27, Zagreb 2003., 171-185.

\section{BURŠIĆ-MATIJAŠIĆ 2007}

Klara Buršić-Matijašić, "Gradine Istre - Povijest prije povijesti", u: Povijest Istre VI, Pula 2007.

\section{BURŠIĆ-MATIJAŠIĆ 2008}

Klara Buršić-Matijašić, Gradinska naselja, Gradine u vremenu i prostoru, Zagreb 2008.

\section{CARDARELLI 1983}

Andrea Cardarelli, "Castellieri nel Carso e nell'Istria: cronologia degli insediamenti fra media età del bronzo e prima età del ferro", u: Preistoria del Caput Adrie, Catalogo della mostra, Trieste 1983, 87-113.

\section{CODACCI-TERLEVIĆ 2006}

Giulia Codacci-Terlević, "Prilog poznavanju brončanodobnih pogrebnih običaji u Istri - stanje istraženosti istarskih tumula te rezultati istraživanja tumula iz uvale Marić kod Barbarige", Histria archaeologica 35/2004., Pula 2006., 41-74.

\section{ČovIĆ 1983}

Borivoj Čović, "Regionalne grupe ranog brončanog doba”, Praistorija jugoslavenskih zemalja IV, Ljubljana 1983.

\section{DIMITRIJEVIĆ ET AL. 1998}

Stojan Dimitrijević - Tihomila Težak-Gregl - Nives Majnarić-Pandžić, Prapovijest, Povijest umjetnosti u Hrvatskoj, Zagreb, 1998.

\section{FABJANOVIĆ ET AL. 2005}

Đuro Fabjanović - Robert Matijašić, "Brijunsko otočje", u: Istarska enciklopedija, Pula 2005., 101-104.

\section{GNIRS 1906}

Anton Gnirs, "Tumulusgräber aus der Kastellierzeit istriens", Mitteilung der Zentralkomission für Kunst und historische Denkmale, Bd. V, Wien 1906, 300-307.

\section{HÄNSEL ET AL. 1999}

Bernhard Hänsel - Kristina Mihovilić - Biba Teržan, "Monkodonja - utvrđeno protourbano naselje starijeg i srednjeg brončanog doba kod 
Rovinja u Istri", Histria archaeologica 28/1997, Pula 1999., 37-108.

\section{HÄNSEL ET AL. 2001}

Bernhard Hänsel - Biba Teržan, "Brončanodobna kupolasta grobnica mikenskog tipa u Istri", Histria Archaeologica 30/1999, Pula 2001., 69107.

\section{HÄNSEL ET AL. 2009}

Bernhard Hänsel - Damir Matošević - Kristina Mihovilić - Biba Teržan, “O socijalnoj arheologiji brončanodobnog utvrđenog naselja i grobova na Monkodonji", Histria archaeologica 38-39, Pula 2009., 81-122.

\section{HERŠAK 2005}

Emil Heršak, Drevne seobe, Prapovijest i stari vijek, Zagreb 2005.

\section{KOMŠO 2008}

Darko Komšo, Pećina Laganiši - mjesto života $i$ smrti, Katalog izložbe, br. 73, Arheološki muzej Istre, Pula 2008., 5-15.

\section{KOVAČ 1994}

Leonida Kovač, "Nezakcijski kult - simboličke forme i njihove transformacije od 6. st. pr. n. e. do 6. st. n. e.", Histria archaeologica 22 - 23/ 1991 - 1992, Pula 1994., 44-116.

\section{MARCHESETTI 1903}

Carlo Marchasetti, I castellieri preistorici di Trieste e della regione Giulia, Trieste 1903, pretisak 1981.

\section{MATIJAŠıĆ 2005}

Robert Matijašić., "Groblja”, Istarska enciklopedija, Pula 2005., 286-287.

\section{MIHOVILIĆ 1986}

Kristina Mihovilić, "L'Istria nella preistoria", u: Archaeologia e arte dell'Istria, Vesna Girardi Jurkić (ur.), svezak 3, Arheološki muzej Istre, Pula 1985., 15-20.

\section{MIHOVILIĆ 1989}

Kristina Mihovilić, "Vetva brončanodobni grob pod tumulom", Arheološki pregled 28, Ljubljana 1989., 73.

\section{MIHOVILIĆ ET AL. 2001}

Kristina Mihovilić - Biba Teržan - Bernhard Hänsel - Damir Matošević - Cornelia Becker, Rovinj prije Rima, Kiel, 2001.

\section{MIHOVILIĆ - KOMŠO 2007}

Kristina Mihovilić - Darko Komšo, "Ripenda", Hrvatski arheološki godišnjak 3 /2006, Zagreb 2007., 265-266.

\section{MIHOVILIĆ ET AL. 2009}

Kristina Mihovilić - Bernhard Hänsel - Biba Teržan - Damir Matošević, Željko Kovačić, Monkodonja i Mušego, Katalog izložbe br. 79, Arheološki muzej Istre, Pula, 2009.

\section{MIHOVILIĆ 2008}

Kristina MIhovilić, "Nekropola u jami Laganiši", Pećina Laganiši, Mjesto života i smrti, Katalog izložbe br. 73, Arheološki muzej Istre, Pula 2008., 45-55.

\section{MIHOVILIĆ 2009}

Kristina Mihovilić, "Postanak", u: Istra kroz vrijeme. Pregled povijesti Istre s osvrtom na grad Rijeku, Egidio Ivetić (ur.), Collana degli Atti Centro Ricerche Storiche Rovigno br. 30, Rovinj - Rovigno 2009, 14-70.

\section{MIHOVILIĆ 2009A}

Kristina Mihovilić, "Gropi - Stari Guran, Analiza prapovijesne keramike", Histria Archaeologica 38-39/ 2007-2008, Pula 2009., 37-79.

\section{MLADIN 1966}

Josip Mladin, “Umjetnički spomenici prahistorijskog Nezakcija", u: Kulturno povijesni spomenici Istre 5, 1966., Pula.

\section{MUMFORD 1988}

Lewis Mumford, "Grad u historiji: njegov postanak, njegovo mijenjanje, njegovi izgledi" Zagreb 1988.

\section{RAJIĆ ŠIKANJIĆ 2009}

Petra Rajić Šikanjić, "Analiza ljudskog skeletnog materijala iz jame Laganiši", Pećina Laganiši, Mjesto života i smrti, Katalog izložbe, br. 73, Arheološki muzej Istre, Pula 2009., 37-44. 


\section{RUARO LOSERI 1983}

Laura Ruaro Loseri, "Sepolture dell'età del bronzo in Carso e in Istria", Preistoria del Caput Adriae, Trieste 1983, 128-129.

\section{SAKARA SUČEVIĆ 2011}

Maša Sakara Saučević, Prazgodovinska keramika med miljskim zalivom in porečjem Mirne, Doktorska disertacija, Univerza na Primorskem, Fakulteta za humanistične študije Koper 2011. (u tisku).

\section{SCHIAVUZZI 1908}

Bernardo Schiavuzzi, "Attraverso l'agro colonico di Pola", Atti e Memorie della Società Istriana di Archaeologia e Storia Patria XXIV, 1908.

\section{TEŽAK-GREGL 2011}

Tihomila Težak-Gregl, Uvod u prapovijesnu arheologiju, Zagreb 2011.

\section{VITASOVIĆ 2002}

Antun Vitasović, "Gradina", Histria archaeologica 31/2000, Pula 2002., 5-6.

\section{SAŽETAK}

Istra je regija s bogatim prapovijesnim nasljeđem, a brončano doba Istre vrlo je zastupljeno po broju istraženih i neistraženih lokaliteta. U 2. tisućljeću pr. Kr. Istru su naselili indoeuropski narodi koji su započeli tradiciju naseljavanja na uzvisinama brda, tzv. gradinama. Osim utvrđenih naselja, brončanodobni stanovnici ostavili su iza sebe i karakteristične kamene grobnice kružnog oblika - tumule, koje lokalno stanovništvo naziva gromače. Podignuti su na vrhovima brda s kojih su ih svi prolaznici mogli zamijetiti. Grobne su škrinje bile sačinjene od nekoliko kamenih ploča, dno je bilo obloženo oblutcima donesenim s obale, na koje se polagao pokojnik u zgrčenom položaju s prilozima. Najčešći grobni prilog bio je jantar te vrlo rijetko brončani bodež. Pojedini tumuli bili su namijenjeni pojedincima, dok su mnogi bili obiteljske grobnice kroz duža razdoblja. Istraženi tumuli dali su mnoga saznanja o stanovnicima Istre tog vremena: njihovom bogatstvu, položaju u društvu, prehrani, običajima te religiji. Najznačajniji istraženi tumuli su Valmarin i Bombište iz ranog brončanog doba te Maklavun i Žamnjak. Ukopi na Monkodonji i susjednom brdu Mušego ujedno su i najistraženiji zbog dugogodišnjeg sustavnog istraživanja. Osim njih, zabilježeni su ukopi u ravnim grobovima s kraja srednjeg brončanog doba, pronađeni na Magornjaku, Šandalji i Krmedu. Nekropole iz Vrčina i Brijuna sa svojim ukopima na ravnom uz zidine gradina pripadaju početku kasnog brončanog doba, dok za monumentalne nezakcijske spomenike postoje ozbiljni argumenti za svrstavanje u isto razdoblje. Mnogi su tumuli devastirani tijekom vremena djelovanjem čovjeka u prostoru, a velik je broj i onih koji su stradali zbog neznanja o toj povijesnoj ostavštini. Tumuli, kao grobna mjesta brončanodobnih stanovnika, još su uvijek nažalost neiskorišten potencijal u povijesnoj ponudi Istre i trebaju u budućnosti doživjeti veću afirmaciju ne bi li se bolje sačuvali za buduće generacije.

\section{SUMMARY}

\section{Funeral rites and burial customs in the Bronze Age in Istria}

Istria is a region of rich prehistoric heritage, from which the archeological sites of the Bronze Age are especially numerous, many still non-researched. In second millennium B.C. Istria was inhabited by Indo-Europeans who started the tradition of living on the top of the hills, 
on the so-called hillforts. The other characteristic feature of those prehistoric inhabitants, besides fortifications, are tumulus - specific stone made, circle shaped graves, which local inhabitants also call gromače. Their position was on the top of the hill in order to be visible to everyone. The tumulus was made of several stone plates, while the bottom of the grave was filled with pebbles from the seashore, on which the deceased was laid in a fetus position, together with some jewelry, pieces or bronze objects or, in some cases, bronze knives or small pearls of amber. Some tumuli were intended only for one person, but family graves of a longer period were more common. The research of tumuli has provided us a lot of new information about the inhabitants of Istria of the time; we can presume how they lived, what was their position in the society, customs and religion. The most important excavated tumuli in Istria are Valmarin and Bombište from the Early Bronze Age, followed by Žamnjak and Maklavun. Monkodonja and Mušego are the two most researched and excavated sites. Other burials from the late Middle Bronze Age can be found in Magornjak, Šandalja and Krmed, where the deceased were found in flat graves. Necropoles from Vrčin and Brijuni have also flat graves which were placed near the entrance of the hillfort, but they are dated in the beginning of the Late Bronze Age. Strong arguments demonstrate that grave monuments from Nezakcij can be dated in that period, too. During centuries, numerous tumuli were devastated by human activities; many of them because of lack of knowledge about this old heritage. Although tumuli are still neglected in the presentation of Istrian history, there is a potential that has to be recognized in order to preserve them for the next generations.

Keywords: Istria, bronze age, hillforts, tumulus, rites, Maklavun, Žamnjak, Monkodonja, grave goods 